\title{
Economic Assessment for Harvesting Artisanal Giant Freshwater Prawn from the Sundarban Mangrove Ecosystem in Bangladesh
}

\author{
Biplab Kumar Shaha ${ }^{a}$, Md. Mahmudul Alam ${ }^{\text {b* }}$, H. M. Rakibul Islam ${ }^{c}$ \\ ${ }^{a}$ Fisheries and Marine Resource Technology \\ Khulna University, Bangladesh \\ E-mail: biplab0623@yahoo.com \\ ${ }^{\mathrm{b}}$ Institute for Environment and Development (LESTARI) \\ National University of Malaysia (UKM), Malaysia \\ E-mail: rony000@gmail.com \\ ${ }^{c}$ Bangladesh Fisheries Research Institute \\ Shrimp Research Station, Bagerhat, Bangladesh \\ E-mail: rakib.bfri@gmail.com \\ * correspondence author
}

\section{Citation Reference:}

Shaha, B.K., Alam, M.M., and Islam, H.M.R. 2014. Economic Assessment for Harvesting Artisanal Giant Freshwater Prawn from the Sundarban Mangrove Ecosystem in Bangladesh, Asia-Pacific Journal of Rural Development, Vol.24 (2), pp. 51-78. (online) https://cirdap.files.wordpress.com/2015/04/apjord-december-20142.pdf

This is a pre-publication copy.

The published article is copyrighted by the publisher of the journal. 


\title{
Economic Assessment for Harvesting Artisanal Giant Freshwater Prawn from the Sundarban Mangrove Ecosystem in Bangladesh
}

\begin{abstract}
Harvesting Giant Freshwater Prawn, Golda (Macrobrachium rosenbergii de Man 1879) in the Sundarnbans mangrove forest plays an important role in the economy of the country as well as the livelihood of local community. The study focused the economic assessment of small-scale artisanal Golda fishery. Overall the Hookline gear showed the best performance in terms of economic return. However, it was found to withstand a shock from $20 \%$ decrease in market prices or $30 \%$ fall in catch rate in terms of Return on investment, payback period and Benefit-cost ratio. Operating cost and fixed cost for Hookline fishery was the lowest and Khathijal was the highest. No significant variation $(\mathrm{P}<0.05)$ observed in the mean catch rate per trip boat ${ }^{-1}$ among the gears studied. Total revenue earned after completion a trip varied considerably between BDT 1,307 to 1,562. Yearly, total net revenue reached at the maximum by Hookline (BDT 38,506), followed by Chandijal (BDT 38,377) and the minimum by Khalpata (BDT 33,885). The findings of this study are supposed to be helpful for policy makers in improving the current status of Golda fishery and relevant human livelihood as well as conserving the Sundarbans Mangrove Ecosystem.
\end{abstract}

Key word: Artisanal Fishery; Giant Freshwater Prawn; Sundarbans Mangrove Ecosystem; Cost Benefit Analysis

\section{Introduction}

The Giant Freshwater Prawn (Macrobrachium rosenbergii), locally called as Galda, is one of the highest valued crustaceans in Bangladesh and also a highly valued product in international markets; almost all prawns are therefore exported, particularly to the USA, Japan, and Europe. Traditionally, freshwater prawns have been caught wild in ponds and marshes (Gain, 1998) through artisanal fisheries across the country. It has been widely distributed in all types of freshwater habitats including the Sundarbans Mangrove Ecosystem (SME) or Sundarbans Reserve Forest (SRF). It also migrates to the costal saline estuaries for breeding.

The species are cultivated across the country in freshwater ponds for export. Between the late 1970s and the mid-1980s, a few pioneering farmers in Fakirhat Upazila (sub-district) in Bagerhat district developed Giant Freshwater Prawn farming technology in small ricefields using mainly rain water and peripheral mud embankments (Rutherford, 1994). In 1976 Bangladesh exported a total of 3,800 mt of shrimps and prawns, and in just twenty years this grew eightfold to $31,500 \mathrm{mt}$. Of this total, approximately $85 \%$ were cultured, half of them are from fresh water. These exports earned 248 million dollars, equivalent roughly to a $3 \%$ share of the world's total shrimp/prawn exports (Vannuccini, 1999). Assuming that the royalty rate is only $12.5 \%$ of the gross value of the products, it can be calculated that the gross value of the fish products in 1990-91 was BDT 112 million (US\$ 2.8 million) (Islam, 2007). In addition, about BDT 30 million (US\$ 750,000) per annum is earned from 60 million $\mathrm{kg}$ of shrimps, mainly tiger prawns, from the Sundarbans and other coastal mangrove areas of Bangladesh (DoF, 2005; BBS, 2005). The revenue generated from fish products increased from Tk. 1.04 million (US\$ 26,000) in 1980-81 to BDT 14.3 million (US\$ 357,000) in 199091 (DoF, 1982; DoF, 1983; DoF, 1991; DoF, 1992; FAO, 2003; MoFL and DANIDA, 2001). An average of 67,195 boats with 165,270 fishermen annually visits the Sundarbans and fish 
for their livelihood (DoF, 2008a). Recent data reveal that the collection of "seed" prawns involves about 25,000 men, women and children (DoF, 2008b). Shell collection also contributes to the employment of young boys and girls (about 550 permit issues each engaging 3-4 people each year). The number of shell collectors increases during the winter tourist season (Rahman et al., 2003; Giasuddin, 2002). Bangladesh exported 46,533 tons of prawn and shrimp in 2005 valued at US\$ 378 million in which $25-30 \%$ was contributed by prawn (DoF, 2006). This figure is expected to rise with the increasing expansion of freshwater prawn cultivation into new areas of Mymensingh district in the north-central part of Bangladesh (Ahmed et al., 2008). The total area under cultivation nationwide is estimated to be around 30,000 ha (Willams, 2003).

A large number of fishing community is involved in Giant Freshwater Prawn fishing from the SME. While there is great potential for increasing family incomes through engaging in prawn cultivation, a number of factors might contribute to the vulnerability of prawn farmers including increased production costs, poor institutional support, and inadequate extension services (Ahmed, 2002); on the other hand, those factors are less effective in wild fishery. With this view, it is essential to the development and management of a fishing unit to know the efficient ways of managing harvesting cost. Harvesting cost data will help the wild fisher in decision making and in adjustment of costs to minimize cost.

However, no information is available on the fishery in general and fisheries economics in particular in the above context in the SME. This study, therefore, was aimed at to assess the economics of Giant Freshwater Prawn fishery from the Sundarbans mangrove ecosystem of Bangladesh. The findings will benefit fishers, researcher and policymakers.

\section{Literature Review}

The existing literature on aquatic species in Bangladesh is by large focused on the farming aspects rather than fishery (Halim et al., 2001; Ling et al., 1999; Huda et al., 2002; Aftabuzzaman, 1998; Thomas et al., 2001; Bhattacharya et al., 1999a and 1999b; Leung and Sharma, 2001; Ling et al., 2001; Shang et al., 2001). Most of the economic analyses carried out in the past in Bangladesh were concentrated on aquaculture production of Giant Freshwater Prawn or Bagda shrimps (Shah et al., 2000; Ito, 2002; Ahmed et al., 2008; Alam et al., 2007; Ahmed, 2001; UNEP, 1999; BCAS, 2001; Quddus et al., 2001). Exploration of the Sundarban mangroves dates back to the 16th century (Rollet, 1981), a large bulk of published literature exists on the Sundarbans of both India (Naskar and Guha Bakshi, 1987; Chaudhuri and Choudhury, 1994; Guha Bakshi et al., 1999) and Bangladesh (Seidensticker et al., 1991; Hussain and Acharya, 1994; Islam and Wahab, 2005) covering many aspects of their habitat characteristics, flora, fauna (particularly fisheries), utilization and management. However, little is known about the functional aspects of this ecosystem.

Information on the economic aspects of fisheries from the Sundarbans is scanty. However, a few review studies reported fragmented information on fisheries economics of capture fisheries from the coastal waters and the Sundarbans mangrove ecosystem of Bangladesh (Hoq et al., 2001; Hoq, 2007; Hoq et al., 2006; Islam and Wahab, 2005; Islam, 2003; Ali et al., 2004; Haque, 2003; Islam and Haque, 2004). However, no information is available on any aspects of economic analysis of any particular fisheries from the Sundarbans. While most of the literatures on culture fisheries reported just the costs of production in an aggregated form, not in any conventional economic analyses covering capital costs, operating costs or variable and fixed costs. Information available so far on the 
demographic features and the economic feasibility in terms of gear efficiency or economic performance are not adequate to get a clear idea on economic returns of wild capture fisheries practiced around the inshore and offshore coastal waters around the SME (BOBP, 1994; BOBP, 1996). However, a number of studies particularly on demersal trawl fisheries in the Bay of Bengal have been undertaken to examine the stock status and scope for future development in harvest. Khan (1983), and White and Khan (1985) have identified the capture fisheries of Bangladesh as complex and multi-species in nature with a number of species are targeted by the fishery. The multiplicity of gear used by the fishers in Bangladesh is to maximize the level of exploitation of a variety of species in a time using a single gear.

Bernacsek (2001) reported that the fishing grounds in the SME are located along the sea-forest boundary spanning an area of $90 \mathrm{~km}$ in length. An intense fishing activity is concentrated in some areas of about $2,250 \mathrm{~km}^{2}$ within $25 \mathrm{~km}$ from shoreline and six heads of the estuaries of $960 \mathrm{~km}^{2}$. Chantarasri (1994) reported fish biology and life histories of eleven most commercially important fish and crustacean species including Giant Freshwater Prawn (Macrobrachium rosenbergii). Bernacsek (2001) also reported the presence of artisanal fishery within the SME with small non-mechanized boats and 14 types of artisanal fishing gears. He reported two types of fishing gears for Giant Freshwater Prawn fishing, namely the angling hook (borshi) and the stick-hook (borshi) fishery using small low valued (BDT. 20

$\mathrm{kg}^{-1}$ ) Chaka chingri (Penaeus indicus) as bait. The angling hook (borshi) is used during winter with an average daily catch of $1 \mathrm{~kg}$ (5-6 individuals) and fishers sold the catch at BDT. $400 \mathrm{~kg}^{-1}$. While the stick-hook is normally operated round the year by one fisherman for 6-10 hrs a day during spring tide periods (20-22 days month $\left.^{-1}\right)$. It is used mainly in small rivers and canals in the upper parts of estuarine of SME.

Thomas et al., (2001) examined the distribution of costs and benefits of shrimp farming. Ling et al., (2001) also gave a comparative analysis of cost and benefits of shrimp farming of the Asian countries including Bangladesh. Bhattacharya et al. (1999a and 1999b) analyzed the gross cost and benefits contributed by the shrimp sector of Bangladesh. They estimated the costs under several categories: i) opportunity costs of land degradation due to salinity, ii) health costs in terms of mortality and morbidity and iii) costs of mangrove destruction. The benefits were estimated based on the income through export of processed shrimp and employment generated by the shrimp sector. However, all those studies are related to the aquaculture economics, but as which is by large different from capture based fisheries economics.

Bostock et al., (2004) mentioned that the owners of small mechanized Giant Freshwater Prawn fishing boats in Bangladesh do not have enough money to finance their journey to the sea. They have to borrow money from the moneylenders and the loan system is the same as the cultured shrimp production system. When these boats land on the shore the boat owners had to sell shrimps to their respective moneylenders or local traders at lower prices to compensate the interest on the borrowed money. The traders then sell the shrimps to the processing factories. The processing factories sell frozen shrimp of various categories sell out their products to the foreign buyers through brokers. Sometimes shrimps are supplied to the factories by depot owners. The moneylenders sell shrimp to the depots which eventually supplies to the processing factories through local Foria/brockers

Locally all Giant Freshwater Prawn catches from the SME are marketed at fresh condition. Quality maintenance facilities (ice or other processing facilities) in the SME are very poor. There is high risk of spoilage of the harvested catch if collector boats respond late. 
There is also a lack of knowledge about sound post-harvest practices (Zafar and Ahsan, 2006). Except a few selective gears (Baited Hookline for Giant Freshwater Prawn or long line for mud crab) most other gear the catches juveniles of high valued fish (however receive low value in the market) and non-target items such as squids, mantis shrimps, snakes etc. at considerable volumes. Islam et al., (1993) estimated the amount of discards at $80 \%$ of the actual catch, which is equivalent to $30,000-35,000 \mathrm{mt}$ annually. This is alarming for the sustainability of fisheries resources in the SME and adjacent coastal waters. Relatively lower capital investment costs than operational costs for almost all the gears in the SME is also encouraging new entry in fishing in the SME by the investors. The costs of fishing crafts and gears along with their repayments were the least important element in comparison to operating costs in the SME. While the rate of depreciation and interest (42.22\%) was high relative to the costs of boats and gears.

The main costs involved in fishing are capital investment and operation costs, which can be further divided into vessel costs, running costs and labor costs (Lery et al., 1999a,b). Tietze et al., (2001) and Lery et al., (1999a and 1999b) mentioned that the major elements of vessel costs are vessel and gear repair and maintenance expenses and vessel insurance. In addition, fishing operations also have external costs, which are sometimes difficult to quantify. External costs are defined as costs which are created by a fishing enterprise for others, i.e. other enterprises or society, for example through depletion of fish stocks or destruction of the coastal ecosystem. However, the FAO definition is for commercial mechanized fishing fleets, which is not applicable to the completely non-mechanized artisanal fisheries of the SME.

\section{Data and Methodology}

This study was conducted through several field surveys in the SME waters covering three administrative ranges (Fig. 1). The SME is located between longitudes $89^{\circ} 00^{\prime} \mathrm{E}$ and $89^{\circ} 55^{\prime}$ E and latitudes $21^{\circ} 30^{\prime} \mathrm{N}$ and $22^{\circ} 30^{\prime} \mathrm{N}$ at the south-west of Bangladesh, encompassing mouth of the 6 estuaries, and numerous rivers, canals and creeks (Giri and Shrestha, 1996; Viju, 1995).

<figure 1>

The study was conducted through 24 individual surveys in the SME of Bangladesh covering 16 rivers/canals and 32 locations (one-third area) of the Sundarbans along the Mongla-Passure-Dubla area within Sharankhola, Chandpai and Khulna ranges between January and December 2006 at fortnightly interval (Table 1).

<table 1>

The data were collected by direct interviews of randomly selected 1,989 fishermen from 545 non-mechanized boats and 1,428 active gears from eight types of gear. This study estimates the following variables for measuring the cost-benefit analysis of the harvesting Giant Freshwater Prawn from SME:

1) Capital costs/fishing unit:

- Construction/purchase costs of crafts;

- Construction/purchase costs of crafts; 
- Purchase costs of radio; and,

- Purchase costs of cooking materials.

2. Operating costs:

a. Variable costs:

- Hired labour;

- Maintenance cost (boat -incidental, boat repairing, boat coating, gear

- Incidental, gear repairing, gear coating and others;

- Food cost;

- Salt cost;

- Bait cost;

- Toll to the pirates

- Illegal office duty (Bribe to the forest officials);

- Depreciation and

- Others

b. Fixed costs:

- Fishing permit

- Fishing revenue

- Boat license certificate (BLC)

- House making cost

- Depreciation

- Others

Further, to conduct the return analysis, data were used to calculate the following ratios:

- Gross profit $($ Tk. $)=$ Gross revenue $($ Income $)$-Total annual operating cost;

- Net profit (tk.) = Total revenue (Tk/trip) - Working capital (Operating costs)

- Rate of return on initial cost $=$ Profit/ Initial cost;

- Rate of return on operating cost $=$ Profit $/$ total cost;

- Return on investment $(\mathrm{ROI})=\{$ Total revenue (Tk/trip) - Working capital (Operating costs) $\} /$ Total investment X 100.

- $\quad$ Payback period (yrs) = initial costs/ (profit+ annual depreciation);

- Break-even price = total operating cost/quantity of production;

- Break-even production = total operating cost/ unit price of the product; and,

- Benefit-cost ratio $(\mathrm{BCO})=$ Total revenue $($ Tk/trip $) /$ Total investment

The data were further analyzed through descriptive statistics (mean, range, standard deviation) by using SPSS software. The seasonal and spatial variation in catch was estimated by using one-way ANOVA. The relationships between the variables were measured by using the Pearson's correlation and regression. To draw inference, $95 \%$ confidence interval was used in the analysis.

While estimating the data, this study considered the following assumptions:

- Income from fishing: Fishing income was considered as the earnings by selling the harvested Giant Freshwater Prawn from the SME area. 
- Labor income: Income of the employee/ labor of fishing boats was not considered as fishing income. The income of self-employed fishers and employee engaged in fishing as labour was estimated separately.

- Fishing period: The time span between the start and end of fishing activity in a year inside the SME was considered as fishing period, i.e total days in a year.

- Method of Harvesting: total eight types of gears and four types of craft were found in this study

- Target species: Among eight types of gears, Hookline was the primary gear used in Giant Freshwater Prawn catching, and the rest seven gears were secondary in nature used in Giant Freshwater Prawn harvest as by-catch. However, this study only considered the income from Giant Freshwater Prawn catching.

\section{Methods of Giant Freshwater Prawn Fishing in SME}

\subsection{Mode of Gear Operation}

Hookline: The Hookline is a baited gear generally used by a single fisher per boat in rivers, small rivers and canals during spring tide phases throughout SME. It is used with small rod (stick), hook and line. About 4-7 sticks with hooks are employed to catch giant freshwater prawn in the SME. Hooks of various numbers, generally 12 in number each with 2-2.2 cm in height are employed. It is operated in daytime, mainly during high tide for 5-6 hrs/day. The fishermen mostly avoid operating this gear during night mainly due to insecurity.

Behundi jal: It is a larger version of the Patajal used to catch small fish and crustaceans which are weak swimmers. It is usually set towards the center of the river channel, and rarely near the shore. Hence no external anchoring is used. It is hauled twice a day, only during low tide phases. The catch is quite low; juvenile shrimp constitute about $98 \%$ of the catch, the rest are juvenile finfish. It is set in every month in the small rivers of the Sundarbans areas during the time of spring tide. This net is set 2-3 times in every 24 hours. Nets are set against the current by fastening the wings to a pair of heavy wooden anchors in deeper water areas, or two wooden poles in shallower water. The mouth of the net is kept open by 2 bamboo poles fastened to the upper and lower lips of the mouth of the bag. A wooden barrel is tied to each end of the wing to serve as a buoy. The cod end is tied with a rope and a float is also attached to it to know the location. A small Balam boat with two men is required to set the net. Hauling is done when the tide runs and after emptying the contents may again be set against the prevailing tide. The fish comes with the tidal current, enters through the mouth and ends up in the bag. The catch consists of crabs, shrimps and many kinds of fresh and brackish water fishes. This net is highly destructive for juvenile fish, shrimp and crab species.

Charpata jal: It is operated in the rivers and khals of the SME. The net is potentially very effective (i.e. destructive) in small rivers and khals, as it is capable of catching virtually all fish, irrespective of size, present in a Khals. The catch composition (i.e., Lates calcarifer, Plotosus canius, Scatophagus aurgus, Jhonius spp., Mugil spp., Arius spp. etc.) is quite different from that of set bagnets. It is used during spring tide. It is set in the intertidal zone of the rivers of the Sundarhans. The net is placed once in a day and it remains under water during high tide. Poles are fixed during low tide along the lowest low tide line and the net is kept folded and embedded into the mud on the ground. The stout ground rope is tied to the poles at the base. The head rope also may be tied above in some places to facilitate the lifting of the net later on during high tide. Food is given when the water of the tide rises on the net from 1 to 1.5 in high; 4 to $5 \mathrm{~kg}$ of the rice particles, rice bran and sago are mixed with water 
and the mixture of these items is applied in the water as the food to attract fish. When high tide has reached to the maximum, fishermen go by boats, raise the net and tie the head rope above the level of water. Two to three fishermen are engaged to operate this net. When the tide turns and water recedes, the crabs, prawns and fishes are stranded and gathered.

Khalpata jal: It is similar to the Charpata jal in length and mesh size but slightly larger in breadth measuring about $4 \mathrm{~m}$. It is a rectangular net of 30-40 $\mathrm{m}$ in length, $2.5-3 \mathrm{~m}$ in breadth and $2-4 \mathrm{~cm}$ in mesh size, operated in estuarine creeks or khals in the Sundarbans.

Gillnet: It is circular in shape and catches fish by gilling or entanglement. Gillnets are anchored to the bottom so that they are not free to move with the water current. They are usually set in rivers and estuaries before high tide. Sometimes the net may serve as a barrier. The fish and crabs get entangled in its meshes. The length of the net depends on the amount of capital available to the operator

Chandijal: It is a set gill net designed for large open water bodies to catch mainly Hilsha during May to October. It also used for fishing Shylong, Rui, Catla, Mrigel, Kalbasu, etc. It is made of several rectangular shaped 11-12 m pieces; jointed together. The mesh size of the net is 1.75 to $5 \mathrm{~cm}$. Both sides of the net are locked with heavy nylon ropes along with floats and sinkers inversely. It is weaved with nylon and polyester fibers, and hanged with bamboo poles from both the side over water that can be operated by boat. The set gill net is operated by $5-10$ fishermen at a time.

Badhajal: This is a type of set bag net, resembling a trawl net, set in the tidal stream by attaching it to holdfasts. It has a rectangular mouth kept open by two vertical bamboo poles. The net is held in a fishing position against the current by linking the extended sides of the net (wing tips) to hold-fasts by means of long bamboo poles and steel wires. The holdfasts are two wooden stakes embedded some distance apart in the sea bed, so that the net is parallel to the direction of the current.

Kathijal: It is locally known as "Jakhi jal" and also called "Khepla" or "Khepla jal". It is a conical shaped net with variable size. The hauling string of the net is fixed at the narrow apical end of the cone. The lower end is folded, doubled up and attached to the net at intervals to form a series of pockets. The margins of the pockets are provided with iron weights as sinker. These nets are thrown into the shallow or moderately deep water from the shore bank or from a slow moving boat. As soon as it is thrown, it goes down quickly due to the weight of the sinkers. When the net is hauled the sinkers disturb the fish in the bottom and make them enter the pockets and are secured there. This net requires mostly smooth bottom for operation. All types of fish are caught by this gear.

\subsection{Crafts Used in Giant Freshwater Prawn Fishing}

The artisanal fishery in the Sundarbans absolutely relies on non-mechanized boats operated by manual oar (Boithya) or sail (Paal) operated by the fishers. Four different types of wooden boats namely, small Balam, small boat, small Dingi and large Nouka were found to operate in the Giant Freshwater Prawn fishery in the SME. The length and width these boats were found to vary from 6.0 to $13.25 \mathrm{~m}$ and 1.0 to $3.2 \mathrm{~m}$, respectively. 
The Balam boat is locally called as 'Behundijal Nouka'which is primarily used in operating Behundijal (setbagnet). However, it is used for operating other gears too, such asBadhajal, Charpata, Chandijal, Gill nets and Longline (Borshi) within SME of Bangladesh. Small Balam boat varied from 7.5-8.5 m in length, 1.5-2.0 m in breadth and 0.7-0.8m in depth. It is made by the mixture of several types of locally available woods such as Chambol, Gewa (Excoecaria agallocha), Jackfruit (Artocarpus heterophyllus) and Jamrul (Lagerstroemia Sp.) etc. The bottom of the boat is round. A pair of wood made oars is used to manipulate the boat. The boat is handled by one to two persons. The carrying capacity of the boat ranges from 800 to $1000 \mathrm{~kg}$. Nine feet long hoods, made of bamboo sticks, to the posterior part of the boat, is used under the hood. The fishermen use the platform (floor) under the hood for cooking and taking rest.

The small boat is locally called 'Charjal Nowka' or 'Choto Nowka'. It is employed for operating a variety of gears namely, single Charpata, Gill nets, Hookline, Kathijal and Khalpata mainly in the rivers and canal within the SME. It varied from 6.0-6.5 $\mathrm{m}$ in length, $1.0-1.2 \mathrm{~m}$ in breadth and 0.6-07 $\mathrm{m}$ in depth. The bottom of the boat is round. A pair of oar, made of wood, is sufficient to manipulate the boat. The boat is handled by two-three fishermen. The carrying capacity of the boat ranges from 400 to $500 \mathrm{~kg}$. This boat is made of wood from Raintree (Samanea saman), Khoi, Sunduri (Heritiera fomes), Gewa (Excoecaria agallocha), Meglan, Betelnut, etc.

The small Dingi, comparatively smaller in size, is locally called 'Chai Nowka'. It is used for the operation of Setbagnet, Baited hookline, Khalpata and for crab traps (bamboo traps). It is $6.5-7.0 \mathrm{~m}$ in length, $1.2-1.5 \mathrm{~m}$ in breadth and $0.6-0.7$ at in depth with round bottom. It is made of locally available Chambol, Gewa (Excoecaria agallocha), Jackfruit (Artocarpus heterophyllus), Jamrul (Lagerstroemia sp.), Kewra (Sonnerata species), Khoiya babla (Acacia nilotica), Khoi, Koroi (Albizzia procera), Raintree (Samanea saman), Badam (Masua ferrea), Sunduri (Heritiera fomes), Meglan and Betelnut wood. The boat is handled by two fishermen. A pair of wooden oar is used to manipulate the boat. The carrying capacity of the boat ranged from 500 to $600 \mathrm{~kg}$.

Large Nouka, locally also known as ' $\mathrm{Nau}$ ' is comparatively larger with round bottom and 7.06 \pm 4.38 (8.78-13.25) $\mathrm{m}$ in length, $1.58 \pm 1.15$ (1.03-3.20) $\mathrm{m}$ in breadth and $1.55 \pm 3.16$ (0.9-1.7) $\mathrm{m}$ in depth. It is used for the operation of Setbagnet, Khalpata, Hilsha gill net, Badhajal, Charpata and Mud crab traps. It is made of locally available woods, namelyChambol, Gewa, Jackfruit, Jamrul, Kewra, Khiyababla, khoi, Koroi, Raintree, Badam, Sunduri, Meglan and Betelnut etc. The boat is handled by two to three fishermen. A pair of wood made oar is used to manipulate the boat. The carrying capacity of this boat ia about 700 to $800 \mathrm{~kg}$.

\section{Economic Assessment of Giant Freshwater Prawn Fishing in SME}

\subsection{Estimation of Costs}

Costs involved in establishing a small-scale (artisanal) Giant Freshwater Prawn fishing unit inside the SME are categorized into capital costs and operating costs. The operating cost includes fixed costs and variable costs. The quantity and unit prices of various items for different gears are presented in the Table 2. Estimated investments costs in terms of capital and operating costs for different gears are shown in Table 3. The capital cost for establishing a Hookline Giant Freshwater Prawn fishing unit is BDT 6,483.90. The capital cost for other 
seven gears varied significantly from BDT 12,075 and BDT 54,810 for the Khalpata and Chandijal fishery, respectively. The operating cost for Hookline fishery was the lowest (BDT 24,052.27 $\mathrm{yr}^{-1}$ ) and Khathijal was the highest (BDT 83,835.56) followed by Gill net.

<table 2, 3>

Fixed costs include boat and gear purchase or construction and repairmen of boats and gears. Fixed costs were calculated annually after deducting the depreciation of crafts and gears over the average crafts and gear life. To calculate depreciation the initial value, salvage value, and lifespan of each depreciable assets were used. Fixed cost was the lowest for Hookline (BDT 9,828.93) and the highest (BDT 65,355.82) for Kathijal.

Variable costs include the cost of bait, marketing (transport van/basket/labor), food cost, preservatives (i.e., salt or ice), tax, fishing permits and on boat maintenance. Food and labor costs increase with the corresponding increase in fishing intensity (days) while other costs remain fairly constant. Variable cost was the highest (BDT 20,002.54) for Charpata and the lowest (BDT 9,606.54) for Badhajal, it was BDT 14223.35 for Hookline.

The share of variable cost, fixed cost, operating cost and capital cost to investment are presented in Table 4. Operating cost was found as the major cost item over capital costs for most of the gears. The operating cost of Hookline was $92 \%$ to the total investment and to be significantly higher than other gear, followed by Gill net (90\%), Kkalpata (83\%) and Kathijal $(78 \%)$. The highest percentage (48\%) of capital cost was found for Chandijal and the lowest (8\%) for Hookline. Variable cost was the highest for Hookline $(54 \%)$ and the lowest for Chandijal (15\%).

\section{<table 4>}

The highest and the lowest percent of fixed cost to total investment were recorded for Gillnet (69\%) and Chandijal (36\%), respectively. The capital cost structure (gear and boat costs) for the artisanal fishing in the SME ranged from BDT 5714 and 54000 for Hookline and Chandijal, respectively. Legal fees included a fishing permit (per trip) and BLC (Boat License Certificate, yearly) from the Forest Department. Marketing costs include transport (van), ice, basket and labor, commission of the Aratdar/wholesaler. Marketing cost was the minimum for all gears (Table 2 and 3). The labor cost was, however, a significant cost component for Behundijal, Charpata, Gillnet, Kathijal and Khalpata.

About $76.92 \%$ of 1,989 respondent fisher received loan. Among them, about $46.5 \%$ fishers received loan for establishing fishing unit (capital costs), 18.3\% for covering fishing trip (operating costs) and $12.12 \%$ for both purpose. This $12.12 \%$ can be attributed as new fishers. About $46 \%$ fisher used 35-45 \% of loan in capital cost, and 23\% fisher used 50-60\% of loan in operating cost. About $42.11 \%$ of total yearly investment was contributed from loan. The amount of loan used for covering capital costs varied from BDT 19,184-24,665 for Chandijal to BDT 2,269-2,918 for Hookline. The amount of loan received to maintain fishing operation was varied from BDT 41,918-50,301 for Kathijal to BDT 12,026-14,431 for Hookline (Table 5). The maximum amount of interest on capital cost was for Chandijal (BDT 8,099-10,413) and the lowest for Hookline (BDT 958-1,232). While the maximum amount of interest on operating cost was varied from BDT 17,698 to 21,237 for Kathijal and BDT 5,077-6,093 for Hookline. The mean maximum amount of interest on capital cost was BDT 9,256 for Chandijal and the minimum BDT 1,095 for Hookline. 
Expenditure per trip was found to be dependent on trip length (days), volume of bait used (operation cost for baited gear increased for bait cost irrespective of lower gear cost), food costs, fishing permit, boat rent, boat maintenance, gear cost, gear repairing cost, etc. Several heads of expenditure (i.e., food, fishing permit, etc.) were the same, but the main factor influenced the expenditure were the gear and boat related expenditures (capital costs). Hence, variation in expenditure was due to gear used for fishing. The lowest expenditure per boat per day in fishing operation (operational cost divided by fishing days) was observed for the Hookline (BDT 143 day $^{-1}$ ) followed by the Behundijal (BDT 207 day $^{-1}$ ), while, it was the highest for the Kathijal (BDT 499 day $^{-1}$ ). However, if the expenditure heads changed to as 'per gear per boat', the expenditure structure will be changed in favor of the gears - Hookline, Chandijal and Gill net, because of highest individual number of gear used with these fishery than the other five gears.

\subsection{Estimation of Benefits}

\subsubsection{Estimated Production:}

Among eight gears operated in the SME, only the Hookline (borshi), is used in catching Giant Freshwater Prawn (Macrobrachium rosenbergii) as target species. However, it catches other high valued fish such as sea bass (Lates calcarifer), mud crab (Scylla olivacea), Indian salmon (Polymenus indicus) etc. as by-catch. Therefore, results have been presented in two categories- i) by Primary gear (Hook-line) that targeted Giant Freshwater Prawn as main catch; and ii) secondary gear (gears that catches Giant Freshwater Prawn as by-catch). Mean daily, seasonal (peak, lean and moderate) and annual catch by different gear (per gear) are presented in Table 6.

\section{$<$ table 6>}

The mean daily catch $\left(\mathrm{kg} \mathrm{day}^{-1} \mathrm{gear}^{-1}\right)$ during peak season by a single hookline was estimated at $0.20 \pm 0.21$ (range: 0.09-0.61) $\left(\mathrm{kg} \mathrm{day}^{-1} \mathrm{gear}^{-1}\right)$. The highest volume was caught by the Kathijal (mean: 1.06 \pm 0.23 ; range: $0.35-1.47$ ) followed by the Badhajal (mean: $1.05 \pm 0.81$; range: $0.84-1.46$ ). The Chandijal harvested the lowest catch (mean: $0.13 \pm 0.10$; range: $0.02-$ 0.54) after the Hookline. During lean season, the daily mean catch of a single Hookline was

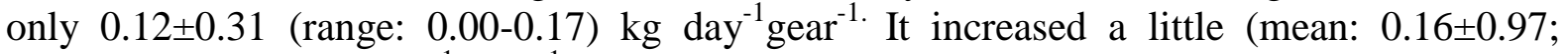
Range: $0.10-0.21 \mathrm{~kg} \mathrm{day}^{-1} \mathrm{gear}^{-1}$ ) during moderate fishing season. The mean highest daily harvest volume $\left(\mathrm{kg} \mathrm{day}^{-1}\right.$ boat $^{-1}$ ) was estimated for the Kathijal at 1.00 \pm 0.96 (range: 0.24-1.17 $\mathrm{kg} \mathrm{day}^{-1}$ boat $^{-1}$ ) followed by the Badhajal at $0.99 \pm 0.27$ (range: 0.26-1.00) and the Hookline at $0.99 \pm 0.42$ (range: 0.06-0.33). The highest annual catch per boat was recorded at $172.80 \mathrm{~kg}$ boat $^{-1} \mathrm{yr}^{-1}$ for the Hookline and the lowest $152.08 \mathrm{~kg}$ for the Khalpata jal.

The variation in catch rates between seasons and gears are probably due to the variation in gear number/boat and fishing day length for different gears. The mean highest number of gear per boat was recorded at 10.00 \pm 3.65 individuals (range: 6.00-14.00) for the Chandijal fishery followed by $6.17 \pm 2.19$ individuals (range: $4.00-9.00$ ) for the Hookline. The pooled seasonal catches per gear $\left(\mathrm{kg} \mathrm{day}^{-1}\right.$ gear $\left.^{-1}\right)$ by all seven gears surveyed were estimated at $4.27 \mathrm{~kg}$ for peak season, $3.14 \mathrm{~kg}$ for lean season and $3.67 \mathrm{~kg}$ for moderate season. The 
annual daily catch rate/gear was $7.56 \mathrm{~kg} \mathrm{day}^{-1} \mathrm{gear}^{-1}$; while total annual catch was estimated to be by all the gears at 1,318.60 kg from 1,428 gears, 545 boats and 1,989 fishers.

\subsubsection{Estimated CPUE:}

The catch per unit effort (CPUE, kg/boat) per day, per trip, per season and per year by eight different gears is presented in Table 7. The mean daily catch rate of Hookline was estimated at $0.99 \pm 0.25 \mathrm{~kg}_{\text {boat }}{ }^{-1} \mathrm{day}^{-1}$. It was $1.24 \pm 1.20,0.75 \pm 0.65$ and $0.99 \pm 0.98 \mathrm{~kg}_{\text {boat }}{ }^{-1}$ day $^{-1}$ for peak season (full dry winter season), lean season (one third of pre-monsoon and three fourth of monsoon) and moderate season (two third of the pre-monsoon and full of the postmonsoon) respectively. Significantly highest mean daily catch per boat $(1.00 \pm 0.06 \mathrm{~kg})$ was obtained from the Kathijal followed by the Badhajal $(0.99 \pm 0.0606 \mathrm{~kg})$. However, the highest daily catch per day was the highest for Candijal $(1.29 \pm 0.76 \mathrm{~kg})$ during peak season, Kathijal $(0.95 \pm 1.02 \mathrm{~kg})$ during lean season and Badhajal $(1.00 \pm 1.25 \mathrm{~kg})$ during moderate season. The catch rate of Hookline was the second $\left(1.24 \pm 1.20 \mathrm{~kg}_{\text {boat }}{ }^{-1}\right.$ day $\left.^{-1}\right)$, during the peak season; fourth $\left(0.75 \pm 0.65 \mathrm{~kg}_{\text {boat }}{ }^{-1} \mathrm{day}^{-1}\right)$ during the lean season and second $\left(0.99 \pm 0.98 \mathrm{~kg}_{\text {boat }}{ }^{-1}\right.$ day $^{-1}$ ) during the moderate season.

\section{<table 7>}

No significant variation $(\mathrm{P}<0.05)$ was observed in the mean catch rate per trip boat ${ }^{-1}$ among the gears studied with the highest catch rate from the Kathijal $(7.01 \pm 0.39 \mathrm{~kg})$ and the lowest from the Khalpata $(5.87 \pm 2.14 \mathrm{~kg})$. The Hookline catch rate at $6.94 \pm 1.65 \mathrm{~kg}$ was very close to the catch rate from of the Behundijal $(6.95 \pm 0.39 \mathrm{~kg})$, Setbagnet/behundijal $(6.48 \pm 0.56 \mathrm{~kg})$, Charpata $(6.37 \pm 2.61 \mathrm{~kg})$, Chandiljal $(6.71 \pm 2.14 \mathrm{~kg})$ and Gill net $(6.59 \pm 1.60$ $\mathrm{kg})$. Variation in catch rate $\left(\mathrm{kg}\right.$ trip $^{-1}$ boat $\left.^{-1}\right)$ by Hookline was insignificant, being the highest $8.67 \pm 1.65 \mathrm{~kg}$ during peak season, $6.94 \pm 1.65$ during moderate season and $5.22 \pm 2.11 \mathrm{~kg}$ during lean season. During the peak (full dry winter season), lean (one third of pre-monsoon and three fourth of monsoon) and moderate season (two third of the pre-monsoon and full of the post-monsoon) per boat per trip catch was recorded at $9.04 \pm 4.12 \mathrm{~kg}, 6.66 \pm 3.12 \mathrm{~kg}$ and $6.98 \pm 2.14 \mathrm{~kg}$ for the Chandijal, Kathijal and Badhajal, respectively.

However, volume of mean catch rate per boat (seasonal catch volume, $\mathrm{Kg}$ ) during peak, moderate and lean fishing season by the Hookline was estimated to be $106.51 \pm 26.35$ $\mathrm{kg}, 48.43 \pm 17.21 \mathrm{~kg}$ and $16.86 \pm 4.11 \mathrm{~kg}$, respectively. The highest catch per boat during peak, lean and moderate season was estimated for the Chandijal $(111.09 \pm 15.36 \mathrm{~kg})$, Badhajal $(16.95 \pm 8.12 \mathrm{~kg})$, and Kathijal $(61.87 \pm 24.22 \mathrm{~kg})$, respectively. The lowest catch was recorded for the Khalpata at $13.12 \pm 6.32 \mathrm{~kg}$. The annual catch rate per boat was estimated at $172.82 \mathrm{~kg}$ for the Hookline, $172.24 \mathrm{~kg}$ for the Chandijal, $171.06 \mathrm{~kg}$ for the Kathijal, $168.88 \mathrm{~kg}$ for the Badhajal, $166.89 \mathrm{~kg}$ for the Gill net, $157.73 \mathrm{~kg}$ for the Setbagnet and $156.89 \mathrm{~kg}$ for the Charpata.

The mean daily CPUE by fisher (kg/day/fisher) for the Hookline was estimated at $0.62 \mathrm{~kg}, 0.50 \mathrm{~kg}$ and $0.37 \mathrm{~kg}$ during peak, moderate and lean fishing seasons respectively (Table 19). While the mean daily CPUE by boat (kg/day/boat) was found to be $4.08 \mathrm{~kg}, 1.62$ $\mathrm{kg}$ and $1.08 \mathrm{~kg}$ during peak, moderate and lean season, respectively. The annual CPUE by per fisher per boat (total season) was the highest for Badhajal $(0.50 \pm 0.03 \mathrm{~kg})$ followed by Hookline $(0.50 \pm 0.12 \mathrm{~kg})$. The annual CPUE for Setbagnet/behundijal, charpata, chandi jal, gill net, kathijal and khalpata was estimated at $0.46 \pm 0.04,0.26 \pm 0.11,0.16 \pm 0.05,0.24 \pm 0.06$, and $0.17 \pm 0.01$ and $0.28 \pm 0.10 \mathrm{~kg}$ respectively. 


\subsection{Assessment of Return}

The daily harvest volume $\left(\mathrm{kg}\right.$ boat $\left.^{-1}\right)$ of Giant Freshwater Prawn varied from $0.84 \pm 0.84$ (0.59-0.13) to $1.00 \pm 0.96$ (1.17-0.24). The income per trip and year for eight different gears are presented in Table 8 and 9, respectively. The volume of harvest $(\mathrm{kg})$ and operating cost (the sum of fixed and variable costs in Tk.) varied significantly between gears. Total revenue earned after completion a trip varied considerably between BDT 1,307.73 for Khalpata and BDT 1,562.48 for Kathijal. Yearly total net revenue reached at the maximum by Hookline (BDT 38,506.56), followed by Chandijal (BDT 38,377.33) and the minimum by Khalpata (BDT 33,885.48).

$<$ table $8,9>$

A significant difference among the key economic indicators was observed between gears in the present study. Revenue earnings only from Giant Freshwater Prawn harvest by seven non-target Giant Freshwater Prawn gears, except the Hookline, were used in the present study and the economic indicators for all fishing gears were found to be poor (Table 8 and 9). However, the best economic performance was posted for the Hhookline. Among 8 gears studied, only two (Bahundijal and Hookline) had positive gross cash flow and they recovered their operating costs with a net profit of 5\% and 55\% after deducting the depreciation and interest, respectively. However, the actual revenues and incomes from white fish and shrimp (other than Giant Freshwater Prawn) by other 7 gears were not included in this study. If the income from the main catch (whitefish and shrimps) are added, all the gears are to be profitable.

Harvesting cost per kilogram of Giant Freshwater Prawn was the lowest (BDT 139.17) and the highest (BDT 490.09) for the Hook-line and the Kathijal, respectively (Table 8 and 9). Return on investments (ROI) was the highest (55.03\%) from Hookline followed by Badhajal (5.82\%) and the lowest (42.42\%) from Kathijal followed by Bahundijal (6.24\%). Based on the above scenario, among 8 different gears used in small-scale artisanal fishery in Giant Freshwater Prawn harvesting, the Hookline showed the best performance in terms of economic return.

The break-even price in respect to total investment was computed considering labor, and equipments in operating and fixed expenses. Break-even prices were calculated based upon two fishing circumstances i.e., per trip harvest and yearly harvest. Significantly higher per trip (BDT 498.12) and per year (BDT 490.09) break-even price was estimated for Kathijal. While the lowest per trip (BDT 144.35) and per year (BDT 139.17) break-even price was estimated for the Hook-line. The profit margins were varied by gears with the highest from Hookline (BDT 14,454.29) and the lowest from Badhajal (BDT 2,915.22).

Some Giant Freshwater Prawn fisher in the SME were found to sell smaller shrimp instead of their own consumption at BDT 50-70 kg to cover the excess expenses. The breakeven analysis for the gear Badhajal showed that the market prices for Giant Freshwater Prawn at BDT $222.81 \mathrm{~kg}^{-1}$ were unprofitable unless all other small shrimp were sold. Results from the economic analysis clearly indicate that marketing of Giant Freshwater Prawn harvested as by-catch from gears other than Hook-line was unprofitable. 
In the present study, total revenue earned after completion a trip varied considerably between BDT 1,307.73 for the Khalpata and BDT 1,562.48 for the Kathijal. Yearly total net revenue reached at the maximum by Hookline (BDT 38,506.56), followed by Chandijal (BDT 38,377.33) and the minimum by Khalpata (BDT 33,885.48). A significant difference in the all economic indicators was observed between gears in the present study. Revenue earning only from Giant Freshwater Prawn harvest by non-target Giant Freshwater Prawn gears except the Hookline were used in the present study and hence the economic indicators for all fishing gears were poor. However, the best economic performance was posted for the Hhookline. However, the actual revenues and incomes from white fish and shrimp (other than Giant Freshwater Prawn) by other 7 gears were not included in this study. If the income from the main catch (whitefish and shrimps) are added, all the gears might be profitable.

Of the eight types of fishing gears studied, only two (Bahundijal and Hookline) had a positive gross cash flow and fully recovered their cost of operation with insignificant profit margins in comparison to other fishing, e.g., mud crab (Zafar and Ahsan, 2006). Though, according to gear based fishing operation in the present study are ranked as (high income to low income) the gear Hookline followed by Badhajal, Chandijal and Khalpata, overall ranking would be Badhajal as this gear engaged in fishing both fish and shrimp (income from fish harvest are avoided in the present study).

The break-even prices were determined for all gear type. Field data of the present study indicate that the expenditure volume and output volume of fishing unit varies widely. Break-even price computed in the Table 8 and 9 shows that a typical small-scale fishing unit selling at this break-even price, except the Badhajal and the Hookline, will not be able to finance their family and further running fishing operation. All types of expenditure have been increased over the past few years. The higher prices paid to producers in 2005-2006 because of high market prices, compared with the previous period, contributed to these overall positive results. Moreover, fishing effort in the SME has been increased and fish stocks have declined (FAO, 1998; DOF, 2008a; Haque, 2003 Barkat and Roy, 2001). Although due to increase in individual fishers, the production and hence net revenue have increased in the SME over the last few years at the cost of ecosystem destruction by various ways (FAO, 1998; DOF, 2008a; WB, 2006; Chantarasri, 1994; Ahmed, 2002).

The result of the present study on the Hookline fishery (target species- Giant Freshwater Prawn) shows a better profit earning than mud crab. Haque et al., (1993b) reported the long-line fishery from Chittagong (south), Cox's Bazar, Noakhali and Patuakhali. They reported a cost and earning analysis showing the variable costs in terms of fuel, food, bait, salt, repairs and replacement of lost or damaged gear. They reported the bait price at BDT 35-45 per kg. The cost of craft and gear were BDT 25,00,000 and 4,000 with an average life 15 years and 1 year, respectively. They estimated monthly average income per fisher at BDT 1,309 for lean season (1-day trip or 25-28 trips per month) and BDT 2,848 for peak season (4-day trips or 6-7 trips per month). Major repairs and maintenance of the boat and gear, about BDT 200 month $^{-1}$, are borne by the boat owner. Therefore, after deducting the depreciation and maintenance cost, the boat owner have a net income of BDT 8,804 month $^{-1}$ during lean season and BDT 9,652 month $^{-1}$ during peak season.

The Hookline fishery of Giant Freshwater Prawn has been found better in terms of economic return and damage to the aquatic biodiversity when compared with the Netjal fishing in the SME reported by Thomas et al., (2001). Thomas et al., (2001) reported that Netjal are devoted for shrimp fry fishing with minor quaintly of mud crab to supply for 
fattening. The cost and benefit analysis shows that taking shrimp production together with shrimp fry collection (undertaken by about $45 \%$ poor and marginal households in the shrimp villages) and fry and shrimp business contributed $60 \%$ of the total household income in the shrimp producing areas. Nevertheless, fishing with Netjal showed a higher profit margin (ROI at $11.61 \%$ to initial cost and $2.12 \%$ to operating cost) in comparison to other gears.

\subsection{Assessment of Risk/ Sensitivity}

A sensitivity analysis to investigate the effect a $20 \%$ decrease in market prices or a $30 \%$ decrease in harvest on net revenue, ROI, PBP and BCO is presented in Table 10. Harvesting Giant Freshwater Prawn shrimp with the Hookline was found to withstand a shock from $20 \%$ decrease in market prices or $30 \%$ fall in catch rate in terms of ROI, PBP and BCO.

$<$ table 10>

However, a 20 fall in market prices and 30 fall in yield were found highly negative to the profitability with the Badhajal as net revenues fall to BDT -4610.5 and BDT -8373.4 (negative value, net loss), respectively.

\section{Conclusion and Recommendation}

The study conducted to focus the economic assessment of small-scale artisanal Giant Freshwater Prawn fishery in the SME of Bangladesh. This study found four types of nonmechanized crafts and eight types of gears used for harvesting Giant Freshwater Prawn. The Hookline has been found as the single primary active gear for Giant Freshwater Prawn fishing. The rest other gears are multi-species and harvests Giant Freshwater Prawn as bycatch. Only $13.60 \%$ of fisher use Hookline, rest of $86.4 \%$ fishers uses seven other gears and $3.24 \%$ of their total catch is Giant Freshwater Prawn harvested as by-catch. Harvest volumes are low for all gears to be insufficient to recover all costs. The harvesting cost per kilogram of Giant Freshwater Prawn was the highest (BDT 139.17) for Hookline and the lowest (BDT 490.09) for Kathijal. The highest daily harvest volume per boat $\left(\mathrm{kg} \mathrm{day}^{-1}\right.$ boat $\left.^{-1}\right)$ are $1.00 \pm 0.96$ for Kathijal followed by $0.99 \pm 0.27 \mathrm{~kg}$ for the Badhajal and $0.99 \pm 0.42 \mathrm{~kg}$ for the Hookline. The highest annual catch per boat $\left(\mathrm{kg} \mathrm{boat}^{-1} \mathrm{yr}^{-1}\right)$ was $172.80 \pm 0.29 \mathrm{~kg}$ for the Hookline followed by $172.24 \pm 0.54 \mathrm{~kg}$ for the Chandijal and was the lowest $152.08 \pm 0.21$ for the Khalpata.

Total revenue earned in a fishing trip varied between BDT 1,307.73 and 1,562.48, with an annual net revenue of BDT 38, 506.56 for Hookline, BDT 38, 377.33 for Chandijal and BDT 33,885.48 for Khalpata. Except the Hookline and Bahundijal, all other six gears studied showed poor economic indicators in terms of gross cash flow and operating costs. Harvesting Giant Freshwater Prawn only with the Hookline can withstand a shock from 20\% decrease in market prices or 30\% fall in catch rate in terms of ROI, PBP and BCO. Therefore, Hookline showed the best economic performance for Giant Freshwater Prawn fishing in the SME over other gears by the small-scale artisanal fishery. Almost eight all the gears examined in this study were profitable, if total catch i.e., fish and Giant Freshwater Prawn are counted. However, the profit-sharing arrangement varies by location, gear type and season.

The Department of Forest is the legal authority in the management of aquatic resources in the waters of the SME of Bangladesh. The authority should care the sustainable 
management of small-scale fisheries to ensure a sustainable growth rate of Giant Freshwater Prawn, and protect over exploitation. At the same time, the authority must care about the inefficient method of fishing that harms other species, such as the set bagnet fishers caught a considerable volume of juveniles and sub-adults of numerous shrimps and fish species as bycatch. Some fishers used long gill and seine nets of 1.5-2.5 cm mesh during November-April, and did severe damage to migratory juvenile Jatka (Hilsha) throughout the Sundarbans. On the other hand, shore seine and canal gillnet fisheries in the inshore area block long area of the shore and the mouths of small canals. These gears are capable of catching virtually all fish (juvenile/adults). The set bagnet and pull and push nets for shrimp post larvae in the inshore area, rivers and canals, also catch enormous numbers of eggs, larvae and fry of many fishes, shrimps, prawn, crabs, and mollusks. Sharks, sawfish and stingrays are also caught by a number of gears. Therefore, to achieve the sustainable management of the Giant Freshwater Prawn fishery and conserving the habitat and flora and fauna in SME, the forest department needs to take proper initiatives and should focuses mostly on the Hookline gear usage for harvesting and increase awareness among fisher not to harm other species.

\section{Acknowledgement}

Authors wish to acknowledge The Fisheries and Marine Resource Technology Discipline, Khulna University for the assistance conducting the research. Our gratitude goes to Professor Dr. Khandakar Anisul Hoq, Professor Dipak Kamal, Alokesh Kumar Ghosh, Mr. Nurul Islam and Mr. Bipul Kumar Nondi for their support at various stages.

\section{References}

Aftabuzzaman, 1998. Sustainable Environment - Friendly Aqua-culture. In Centre for Policy Dialogue, Environmental Consequences of Export Oriented Shrimp Culture in Bangladesh, CPD Dialogue Report No. 18, Centre for Policy Dialogue, Dhaka, Bangladesh. 78.

Ahmed, N., 2001. Socio-Economic Aspects of Freshwater Prawn Culture Development in Bangladesh. PhD thesis, University of Stirling, UK. 256.

Ahmed, N., 2002. Socio-economic aspects of freshwater prawn culture development in Mymensingh, Bangladesh. International Center for Living Aquatic Resources Management (ICLARM) Report. Dhaka, Bangladesh. 118-122.

Ahmed, N., Ahammed, F. and Brakel, M.V., 2008. An Economic Analysis of Freshwater Prawn, Macrobrachium rosenbergii, Farming in Mymensingh, Bangladesh. Journal of the World Aquaculture Society, 39(1): 37-50.

Alam, S.M.N., Pokrant, B., Yakupitiyage, A. and Phillips, M.J., 2007. Economic returns of disease-affected extensive shrimp farming in southwest Bangladesh, Aquacult Int. 15:363-370.

Ali, M.Y., Kamal, D., Hossain, S.M.M., Azam, M.A., Sabbir, W., Murshida, A., Ahmed, B. and Azam, K., 2004. Biological Studies of the Mud Crab, Scylla serrata (Forskal) of the Sundarbans Mangrove Ecosystem in Khulna Region of Bangladesh. Pakistan Journal of Biological Sciences 7 (11): 1981-1987.

BBS, 2005. "Statistical Yearbook of Bangladesh: 2005", Bangladesh Bureau of Statistics, Statistics Division, Ministry of Planning, Government of the People's Republic of Bangladesh, Dhaka, Bangladesh.

BCAS, 2001. The costs and benefits of bagda shrimp farming in Bangladesh - an economic, financial and livelihoods assessment. Prepared as part of the Fourth Fisheries Project by Bangladesh Centre for Advanced Studies. August 2001. 
Bernacsek, G., 2001. Catalogue of fishing gears of the Sundarbans and marine zone. Draft report. Sundarbans biodiversity conservation project, Aquatic resources programme, Khulna, Bangladesh

Bhattacharya, D., Rahman, M. and Khatun, F.A., 1999a. Environmental Impact of Trade Liberalization and Policies for the Sustainable Management of Natural Resources: A Case Study on Bangladesh's Shrimp Farming Industry, Centre for Policy Dialogue (CPD), Dhaka, Bangladesh.

Bhattacharya, D., Rahman, M. and Khatun, F.A., 1999b. Environmental Impact of Structural Adjustment Policies: The Case of Export Oriented Shrimp Culture in Bangladesh. (CPD), Dhaka, Bangladesh.

BOBP, 1994. "Biosocioeconomic Assessment of the Effect of the Estuarine SetBagnet on the Marine Fisheries of Bangladesh", Bay of Bengal Programme (BOBP), Madras, India.

BOBP, 1996. "Towards Sustainability: Needs and Concerns of Aquatic Resources and Fisheries in the Bay of Bengal Region and Project Ideas to Facilitate Their Sustainable Management", Madras, India.

Bostock, T., Greenhalgh, P. and Kleih, U., 2004. Policy Research - Implications of Liberalization of fish Trade for Developing Countries - Synthesis Report. Chatham, UK: Natural Resources Institute. ISBN 0 85954 560-1.

Chantarasri, S., 1994. Fisheries resources management for the Sundarbans reserved forest. In: Integrated resource development of the Sundarbans reserved forest, Bangladesh (BGD/84/056), Fourth draft final report. Khulna, Bangladesh: FAO/UNDP, 1994, $171 \mathrm{pp}$.

Chaudhuri, A.B. and Choudhury, A., 1994. Mangroves of the Sundarbans. Vol. 1, India. IUCN, Bangkok, Thailand.

DoF (Department of Fisheries), 1982. Fisheries week 1982. Souvenir. Department of Fisheries, Fisheries and Livestock Department. Dhaka.

DoF (Department of Fisheries), 1983. Fish Catch Statistics of Bangladesh, Bangladesh Fishery Resources Survey System. BFRSS, Department of Fisheries, Dhaka, Bangladesh.

DoF (Department of Fisheries), 1991. Fish Catch Statistics of Bangladesh, Bangladesh Fishery Resources Survey System. BFRSS, Department of Fisheries, Dhaka, Bangladesh.

DoF (Department of Fisheries), 1992. Fish Catch Statistics of Bangladesh, Bangladesh Fishery Resources Survey System. BFRSS, Department of Fisheries, Dhaka, Bangladesh.

DoF (Department of Fisheries), 2005. Fish Catch Statistics of Bangladesh, Bangladesh Fishery Resources Survey System. BFRSS, Department of Fisheries, Dhaka, Bangladesh.

DoF (Department of Fisheries), 2006. Fish Catch Statistics of Bangladesh, Bangladesh Fishery Resources Survey System. BFRSS, Department of Fisheries, Dhaka, Bangladesh.

DoF (Department of Fisheries), 2008a. Fish Catch Statistics of Bangladesh, Bangladesh Fishery Resources Survey System. BFRSS, Department of Fisheries, Dhaka, Bangladesh.

DoF (Department of Fisheries), 2008b. Fishery Statistical Yearbook of Bangladesh 20062007. Fisheries Resources Service System, Department of Fisheries (DOF), Ministry of Fisheries and Livestock, Dhaka, Bangladesh, 42.

FAO, 1998. Disease prevention and health management of coastal shrimp culture. Food and Agriculture Organization of the United Nations, Bangkok, Thailand. TCP/BGD/6714, Field Document 3. 
FAO, 2003. Globefish Commodity Update: Shrimp. Food and Agriculture Organization of the United Nations. June 2003.

Giasuddin, M.K. $(E d), 2002$. Review of the current knowledge on coastal shrimp fry collection and it's impact on biodiversity. Fourth Fisheries Project report -2002 on PL Fishery Management Action Plan, Department of Fisheries, Ministry of Fisheries \& Livestock, Dhaka, Bangladesh, , supported by Global Environment Facility/World Bank under Aquatic Resources Development, Management and Conservation Studies

Giri, C. and Shrestha, S., 1996. Land cover mapping and monitoring from NOAA AVHRR data in Bangladesh. International Journal of Remote Sensing, 17 (14): 2749-2759.

Guha, Bakshi, D.N., Sanyal, P. and Naskar, K.R. (Eds.), 1999. Sundarbans Mangal. Naya Prokash, Calcutta, 771 pp.

Halim, S., Hoq, M.E., Kamal, M. and Wahab, M.A., 2001. Feasibility study for the shrimp component of the Fourth Fisheries Project: Women and children study. Prepared by Bangladesh Centre for Advanced Studies, Dhaka, July 2001.

Haque, M.E., 2003. How fishers' endeavors and information help in managing the fisheries resources of the Sundarban mangrove forest of Bangladesh, University of British Columbia, Fisheries Center Research Report 11(1): 433-438.

Haque, Q.M., Khan, M.G., Chowdhury, Z.A. and Sarker, M.N., 1993b. The Bottom Longline Fishery for Croaker (Sciaenidae). p. 107-117. In Studies of interactive marine fisheries of Bangladesh. BOBP/WP/89.

Hoq, M.E., 2007. An analysis of fisheries exploitation and management practices in Sundarbans mangrove ecosystem, Bangladesh. Ocean \& Coastal Management, 50: 411-427.

Hoq, M.E., Islam M.N., Kamal, M. and Wahab, M.A., 2001. Abundance and seasonal distribution of Penaeus monodon postlarvae in the Sundarbans mangrove, Bangladesh. Hydrobiologia, 457: 97-104.

Hoq, M.E., Wahab, M.A. and Islam, M.N., 2006. Hydrographic status of Sundarbans mangrove, Bangladesh with special reference to post-larvae and juveniles fish and shrimp abundance. Wetlands Ecology and Management, 14: 79-93.

Huda, F.A., Salehin, M.M. and Khan, M.I., 2002. Economics of Periphyton-Based Aquaculture Production in Bangladesh. On Line Journal of Biological Sciences, 2 (8): 518-519.

Hussain, Z. and Acharya, G. (Eds.), 1994. Mangroves of the Sundarbans. Volume 2: Bangladesh. World Conservation Union, Gland, 257 p.

Islam, M.N. (Ed.), 2007. Annual Report, 2005-2006. Department of Fisheries, Ministry of Fisheries \& Livestock, Dhaka, Bangladesh, pp. 32-34.

Islam, M.S. and Haque, M., 2004. The mangrove-based coastal and nearshore fisheries of Bangladesh: ecology, exploitation and management. Reviews in Fish Biology and Fisheries, 14: 153-180.

Islam, M.S. and Wahab, M.A., 2005. A review on the present status and management of mangrove wetland habitat resources in Bangladesh with emphasis on mangrove fisheries and aquaculture. Hydrobiologia, 542: 165-190.

Islam, M.S., 2003. Perspectives of the coastal and marine fisheries of the Bay of Bengal, Bangladesh. Ocean \& Coastal Management, 46: 763-796.

Islam, M.S., Khan, M.G., Quayum, S.A., Sada, M.N.U. and Chowdhury, Z.A., 1993. The estuarine set bag net fishery. In: Studies of interactive Marine Fisheries of Bangladesh. Bay of Bengal Program, Madras, India, BOBP/WP/89: 9-50.

Ito, S., 2002. From rice to prawns: economic transformation and agrarian structure in rural Bangladesh. The Journal of Peasant Studies, 29(2): 47-70. 
Khan, M.G., 1983. Results of the 13th Cruise (July, 1983) with the R.V. Anusandhani of the demersal fish and shrimp ground of the Bay of Bengal, Bangladesh. Marine Fisheries Survey, Management and Development Project, GOB, Chittagong.

Leung, P. and Sharma, K.R. (Eds.).. 2001: Economics and Management of Shrimp and Carp Farming in Asia: A collection of Research Papers based on the ADB/NACA Farm Performance Survey, Network of Aquaculture Centres in Asia-Pacific (NACA), Bangkok, Thailand.

Ling, B.H., Leung, P.S. and Shang, Y.C., 2001. Comparing Asian Shrimp Farming the Domestic Resource Cost (DRC) Approach. In Leung P.S. and Sharma K.K. (Eds.), Economic and Management of Shrimp and Carp Farming in Asia, Network of Aquaculture Centers in Asia Pacific, Bangkok, Thailand.

Ling, B-H, Leung, P.S. and Shang, Y.C., 1999. Comparing Asian shrimp farming: the domestic resource cost approach. Aquaculture, 175: 31-48.

MoFL, and DANIDA., 2001. "Feasibility study on fresh water prawn (Macrobrachium rosenbergii)". Prospect of fresh water prawn culture at GNAEP and PBAEP areas, under Aquaculture Extension Project (GNAEP) \& Potuakhali Borguna Aquaculture Extension Project (PBAEP), Grant NO., 104 Bang., pp. 805-13.

Naskar, K.R. and Guhabakshi, D.N., 1987. Mangrove Swamps of the Sundarbans - An Ecological Perspective. Naya Prokash, Calcutta, 263 p.

Quddus, A.H.G., Rutherford, S. and Phillips, M., 2001. Final Report on Livelihood Analysis under Shrimp Sector. Social Feasibility Studies of the Fourth Fisheries Project.

Rahman, M.M., Chowdhury, Z.A. and Sada, M.N.U., 2003. Coastal resources management, policy and planning in Bangladesh, pp. 689-756. In: G. Silvestre, L. Garces, I. Stobutzki, M. Ahmed, R.A. Valmonte-Santos, C. Luna, L. Lachica-Aliño, P. Munro, V. Christensen and D. Pauly (Eds.) Assessment, Management and Future Directions for Coastal Fisheries in Asian Countries. WorldFish Center Conference Proceeding, 67: 1-120.

Rollet, B., 1981. Bibliography on Mangrove Research 1600-1975. UNESCO, Paris, 479 pp.

Rutherford, S., 1994. CARE and Gher: Financing the Small Fry. Report prepared for CARE International in Bangladesh with support from the Bangladesh Aquaculture and Fisheries Resource Unit (BAFRU).

Seidensticker, J., Kurin, R. and Townsend, A.K. (Eds.), 1991. The Commons in South Asia: Societal Pressures and Environmental Integrity in the Sundarbans. The International Center, Smithsonian Institution, Washington, D.C.

Shah, W.A., Phillips, M., Kamal, S., Jahan, I. and Sarker, J., 2000. The Economics of Bagda Shrimp (Penaeus Monodon) Farming in Coastal Areas of Bangladesh. In: Sen S (Ed.), Grassroots Voice Volume-III, (Issues I \& II), Bangladesh Resource Centre for Indigenous Knowledge, Dhaka, Bangladesh.

Shang, Y.C., Leung, P.S. and Ling, B.H., 2001. Comparative Economics of Shrimp Farming in Asia. In: Leung P.S. and Sharma K.K. (Eds.), Economic and Management of Shrimp and Carp Farming in Asia. Network of Aquaculture Centres in Asia-Pacific, Bangkok, Thailand.

Thomas, M.A., Macfadyen, G. and Chowdhury, S., 2001. The costs and Benefits of Bagda Shrimp Farming in Bangladesh. Bangladesh Centre for Advanced Studies, Dhaka, Bangladesh.

Tietze, U., Prado, J., Le, R. J.-M and Lasch, R., 2001. Techno-economic performance of marine capture fisheries. In: FAO Fisheries Technical Paper No. 421, Rome, 79 pp.

UNEP, 1999. Environmental Impacts of Trade Liberalization and Policies for the Sustainable Management of Natural Resources: A Case Study on Bangladesh's Shrimp Farming Industry. United Nations Environment Programme, New York and Geneva. 
Vannuccini, S., 1999. The Bangladeshi Shrimp Industry. URL: http://www.fao.org/fi/globe/ blogfish/fishery/globefi/doc/presenta/bangle.

Viju, I.C. 1995. Issues in the management of the environment and natural resources in Bangladesh. Journal of Environmental Management, 45 (4): 319-332.

WB, 2006 (World Bank). Bangladesh Fisheries Sector Review. Document of the World Bank, FAP 12/13 project, Report No. 8830-bd.

White, T.F. and Khan, M.G., 1985. The marine fishery resources of Bangladesh and their potential for commercial development. Key note Paper Presented at the National Seminar on Fisheries Development in Bangladesh, Dhaka, January, Souvenir, 1985, pp. 1-4.

Willams, D., 2003. Freshwater prawn farming in Bangladesh. Fish Farmer, 26(5): 24-27.

Zafar, M. and Ahsan. M.N., 2006. Marketing and Value Chain Analysis of Mud Crab (Scylla sp.) in the Coastal Communities of Bangladesh, Research Project Final Report, funded by AFGRP, DFID and BFRF, Dhaka, Bangladesh, pp. 30-61. 


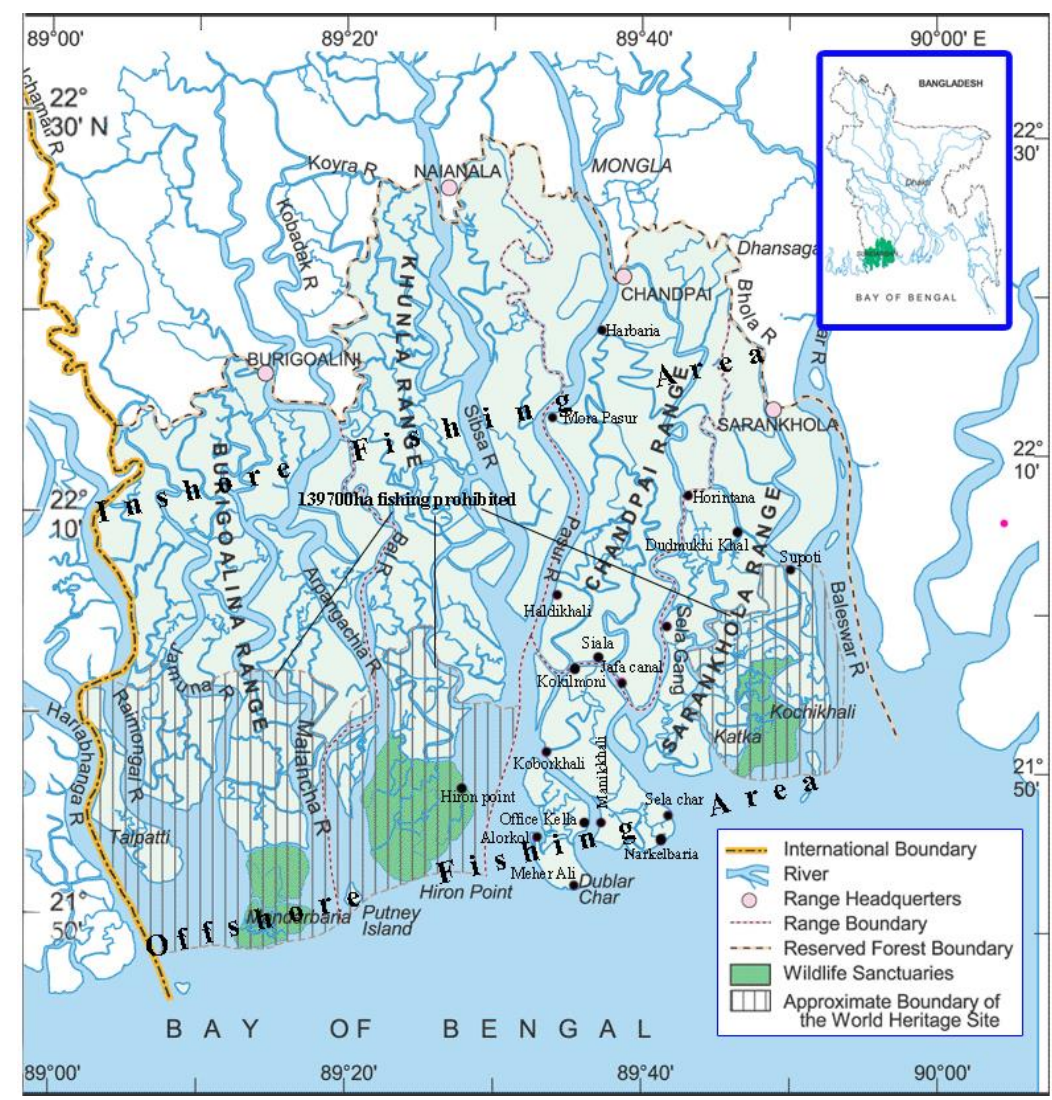

Figure 1: Map of Sundarbans where Range Headquarters are study areas 
Table 1: The GPS locations of the survey areas in the SME

\begin{tabular}{llll}
\hline N Latitude & E Longitude & N Latitude & E Longitude \\
\hline $21^{\circ} 17^{\prime} 08.8^{\prime \prime}$ & $89^{\circ} 34^{\prime} 22.6^{\prime \prime}$ & $21^{\circ} 55^{\prime} 090^{\prime \prime}$ & $89^{\circ} 33^{\prime} 897^{\prime \prime}$ \\
$21^{\circ} 17^{\prime} 11.6^{\prime \prime}$ & $89^{\circ} 38^{\prime} 52.0^{\prime \prime}$ & $21^{\circ} 56^{\prime} 44.4^{\prime \prime}$ & $89^{\circ} 34^{\prime} 59.5^{\prime \prime}$ \\
$21^{\circ} 44^{\prime} 78.4^{\prime \prime}$ & $89^{\circ} 33^{\prime} 27.6^{\prime \prime}$ & $22^{\circ} 14^{\prime} 90.7^{\prime \prime}$ & $89^{\circ} 36^{\prime} 32.4^{\prime \prime}$ \\
$21^{\circ} 45^{\prime} 15.0^{\prime \prime}$ & $89^{\circ} 32^{\prime} 51.8^{\prime \prime}$ & $22^{\circ} 37^{\prime} 11.6^{\prime \prime}$ & $89^{\circ} 29^{\prime} 96.7^{\prime \prime}$ \\
$21^{\circ} 46^{\prime} 09.8^{\prime \prime}$ & $89^{\circ} 32^{\prime} 52.2^{\prime \prime}$ & & \\
\hline
\end{tabular}

Table 2: Investment costs for different fishing units for Giant Freshwater Prawn harvest in the SME of Bangladesh.

\begin{tabular}{|c|c|c|c|c|c|c|c|c|c|c|c|c|c|c|c|c|c|}
\hline \multirow[t]{2}{*}{ Cost items } & \multirow[t]{2}{*}{ Unit } & \multicolumn{2}{|l|}{$\mathbf{H}$} & \multicolumn{2}{|l|}{$\mathbf{B}$} & \multicolumn{2}{|l|}{ BJ } & \multicolumn{2}{|l|}{$\mathbf{C}$} & \multicolumn{2}{|l|}{$\mathbf{C J}$} & \multicolumn{2}{|l|}{$\mathbf{G}$} & \multicolumn{2}{|l|}{$\mathbf{K}$} & \multicolumn{2}{|l|}{ Kp } \\
\hline & & $1 *$ & $2 * *$ & $1 *$ & $2 * *$ & $1 *$ & $2 * *$ & $1 *$ & $2 * *$ & $1 *$ & $2 * *$ & $1 *$ & $2 * *$ & $1 *$ & $2 * *$ & $1 *$ & $2 * *$ \\
\hline \multicolumn{18}{|l|}{ A. Capital costs (for establishment) } \\
\hline 1. Boat construction/purchase & No. & 2230 & 1 & 12563 & 1 & 9000 & 1 & 7351 & 1 & 13000 & 1 & 7000 & 1 & 19050 & 1 & 6950 & 1 \\
\hline 2. Gear construction/purchase & No. & 490 & 7 & 7010 & 2 & 14500 & 1 & 11625 & 2 & 4100 & 10 & 350 & 5 & 12750 & 1 & 2100 & 2 \\
\hline 3. Cooking material & LS & 560 & 1 & 850 & 1 & 650 & 1 & 560 & 1 & 550 & 1 & 500 & 1 & 650 & 1 & 640 & 1 \\
\hline 4. Radio & No. & 90 & 1 & 90 & 1 & 90 & 1 & 90 & 1 & 90 & 1 & 90 & 1 & 90 & 1 & 90 & 1 \\
\hline 5. Other equipment (if any) & LS & 120 & 1 & 150 & 1 & 140 & 1 & 150 & 1 & 170 & 1 & 180 & 1 & 190 & 1 & 195 & 1 \\
\hline \multicolumn{18}{|l|}{ B. Operating costs (yearly and to run): } \\
\hline \multicolumn{18}{|l|}{ B1. Variable cost } \\
\hline 1. Food & Tk. & 371 & 14 & 252 & 42 & 272 & 10 & 159 & 52 & 121 & 16 & 189 & 32 & 194 & 45 & 176 & 45 \\
\hline 2. Bait cost & $\mathrm{Kg}$ & 39 & 55 & 0 & 0 & 0 & 0 & 0 & 0 & 0 & 0 & 0 & 0 & 0 & 0 & 0 & 0 \\
\hline 3. Preservative cost (e.g., salt) & $\mathrm{Kg}$. & 13 & 35 & 13 & 18 & 13 & 37 & 13 & 61 & 13 & 69 & 13 & 9 & 13 & 85 & 13 & 17 \\
\hline 4. Fuel (Other than boat operation) & $\mathrm{L}$ & 36 & 33 & 36 & 20 & 36 & 500 & 36 & 40 & 36 & 32 & 36 & 32 & 36 & 24 & 36 & 36 \\
\hline 7. Others ${ }^{\wedge}$ & $\mathrm{Tk}$ & 250 & 18 & 350 & 17 & 500 & 10 & 430 & 20 & 500 & 16 & 450 & 16 & 600 & 12 & 350 & 18 \\
\hline 8. Marketing (Van/basket/labor) & Tk day $^{-1}$ & 50 & 18 & 70 & 17 & 140 & 10 & 45 & 20 & 135 & 16 & 65 & 16 & 50 & 12 & 115 & 18 \\
\hline \multicolumn{18}{|l|}{ B2. Fixed costs } \\
\hline 1.Salary/wage of labor(shareholder) & month & 0 & 0 & 1046 & 12 & 0 & 0 & 1092 & 12 & 0 & 0 & 1600 & 12 & 3920 & 12 & 788 & 12 \\
\hline 2.Boat rent & year & 0 & 0 & 0 & 0 & 0 & 0 & 0 & 0 & 0 & 0 & & 0 & 0 & 0 & 0 & 0 \\
\hline 3.Gear rent & year & 0 & 0 & 0 & 0 & 0 & 0 & 0 & 0 & 0 & 0 & 0 & 0 & 0 & 0 & 0 & 0 \\
\hline 4.Interest on half of capital costs at $42.22 \%$ & Tk. & & & & & & & & & & & & & & & & \\
\hline 5.Depreciation of boat + gear price & Tk. & & & & & & & & & & & & & & & & \\
\hline
\end{tabular}




\begin{tabular}{|c|c|c|c|c|c|c|c|c|c|c|c|c|c|c|c|c|c|}
\hline 6. Govt. duty & Tk. trip $^{-1}$ & 6 & 18 & 6 & 42 & 6 & 10 & 6 & 52 & 6 & 16 & 6 & 32 & 6 & 48 & 6 & 45 \\
\hline 4. Boat maintenance (repairing+coating) & Tk. trip $^{-1}$ & 310 & 2 & 469 & 2 & 250 & 2 & 913 & 2 & 754 & 2 & 160 & 2 & 759 & 2 & 256 & 2 \\
\hline 5. Gear maintenance (repairing+coating) & Tk. $\operatorname{trip}^{-1}$ & 350 & 14 & 867 & 17 & 1555 & 10 & 263 & 20 & 1546 & 16 & 1773 & 16 & 690 & 11 & 809 & 18 \\
\hline
\end{tabular}

5. Gear maintenance (repairing+coating)

Setbagnet/ Behundijal (B); Badha jal (BJ); Charpata (C); Chandi jal (CJ); Gillnet (G); Hookline (H); Kathijal (K); Khal Pata (KP).

$\wedge$ Incidental + pirates+ illegal duty +etc. Give the years of boat and gear life for estimating depreciation

$1 *=$ Unit price; $2 * *=$ Quantity; Unit prices and values along columns are in BDT, BDT $65.00=1$ US\$

Table 3: Investment cost (Tk. / year) for a Giant Freshwater Prawn fishing unit in the Sundarbans mangrove ecosystem.

\begin{tabular}{|c|c|c|c|c|c|c|c|c|}
\hline Cost items & $\mathbf{H}$ & $\mathbf{B}$ & BJ & $\mathbf{C}$ & $\mathbf{C J}$ & $\mathbf{G}$ & $\mathbf{K}$ & $\mathbf{K p}$ \\
\hline A. Capital costs (for establishment) & Value & Value & Value & Value & Value & Value & Value & Value \\
\hline 1. Boat construction/purchase & 2230.00 & 12562.50 & 9000.00 & 7351.24 & 13000.00 & 7000.00 & 19050.00 & 6950.00 \\
\hline 2. Gear construction/purchase & 3483.90 & 14020.00 & 14500.00 & 28416.47 & 41000.00 & 1750.00 & 12750.00 & 4200.00 \\
\hline 3. Cooking material & 560.00 & 850.00 & 650.00 & 560.00 & 550.00 & 500.00 & 650.00 & 640.00 \\
\hline 4. Radio & 90.00 & 90.00 & 90.00 & 90.00 & 90.00 & 90.00 & 90.00 & 90.00 \\
\hline 5. Other equipment (if any) & 120.00 & 150.00 & 140.00 & 150.00 & 170.00 & 180.00 & 190.00 & 195.00 \\
\hline Subtotal (A) & 6483.90 & 27672.50 & 24380.00 & 36567.72 & 54810.00 & 9520.00 & 32730.00 & 12075.00 \\
\hline \multicolumn{9}{|l|}{ B. Operating costs (yearly and to run): } \\
\hline \multicolumn{9}{|l|}{ B1. Variable cost } \\
\hline 1. Food & 5122.15 & 10555.09 & 2715.00 & 8272.14 & 1933.71 & 6032.00 & 8706.93 & 7920.00 \\
\hline 2. Bait cost & 2146.67 & 0.00 & 0.00 & 0.00 & 0.00 & 0.00 & 0.00 & 0.00 \\
\hline 3. Preservative cost (e.g., salt) & 459.33 & 239.43 & 480.00 & 790.40 & 896.00 & 112.00 & 1108.80 & 216.00 \\
\hline 4. Fuel (Other than boat operation) & 1195.20 & 720.00 & 11.54 & 1440.00 & 1152.00 & 1152.00 & 864.00 & 1296.00 \\
\hline 7. Others (incidental + pirates+ illegal duty +etc.) & 4416.67 & 5810.00 & 5000.00 & 8600.00 & 8000.00 & 7200.00 & 7200.00 & 6300.00 \\
\hline 8. Marketing (Van/basket/labor) & 883.33 & 1162.00 & 1400.00 & 900.00 & 2160.00 & 1040.00 & 600.00 & 2070.00 \\
\hline Subtotal (B1) & 14223.35 & 18486.52 & 9606.54 & 20002.54 & 14141.71 & 15536.00 & 18479.73 & 17802.00 \\
\hline \multicolumn{9}{|l|}{ B2. Fixed costs } \\
\hline 1. Salary/wage of labor(shareholder) & 0.00 & 12557.69 & 0.00 & 13106.36 & 0.00 & 19200.00 & 47040.00 & 9450.00 \\
\hline 2. Boat rent & 0.00 & 0.00 & 0.00 & 0.00 & 0.00 & 0.00 & 0.00 & 0.00 \\
\hline 3. Gear rent & 0.00 & 0.00 & 0.00 & 0.00 & 0.00 & 0.00 & 0.00 & 0.00 \\
\hline
\end{tabular}




\begin{tabular}{|c|c|c|c|c|c|c|c|c|}
\hline 5. Depreciation of boat + gear price & 4270.96 & 7928.29 & 9000.00 & 6998.09 & 9500.00 & 2150.00 & 8779.26 & 2712.50 \\
\hline 6. Govt. duty & 108.52 & 254.93 & 61.43 & 318.20 & 98.29 & 196.57 & 294.86 & 276.43 \\
\hline 4. Boat maintenance (repairing + coating) & 619.44 & 937.90 & 500.00 & 1825.47 & 1508.62 & 320.93 & 1518.75 & 512.50 \\
\hline 5. Gear maintenance (repairing + coating) & 4830.00 & 14508.32 & 15545.50 & 5255.41 & 24728.00 & 28364.00 & 7722.96 & 14563.80 \\
\hline Subtotal (B2) & 9828.93 & 36187.13 & 25106.93 & 27503.54 & 35834.91 & 50231.50 & 65355.82 & 27515.23 \\
\hline Total operating costs $(\mathrm{B} 1+\mathrm{B} 2)$ & 24052.27 & 54673.65 & 34713.47 & 47506.07 & 49976.62 & 65767.50 & 83835.56 & 45317.23 \\
\hline Total investment (A+B)- B2 (6) & 26265.21 & 74417.86 & 50093.47 & 77075.70 & 95286.62 & 73137.50 & 107786.30 & 54679.73 \\
\hline
\end{tabular}

Unit prices and values along columns are in BDT, BDT 65.00=1 US\$

Table 4: Percent of fixed, variable, operating and capital costs to total investment for eight fishing gears in the SME.

\begin{tabular}{|l|l|l|l|l|l|l|l|l|}
\hline Gear & H & B & BJ & C & CJ & G & K & Kp \\
\hline Variable cost (\% of total) & 54 & 25 & 19 & 26 & 15 & 21 & 17 & 33 \\
\hline Fixed cost (\% of total) & 37 & 49 & 50 & 36 & 38 & 69 & 61 & 50 \\
\hline Operating cost (\% of total) & 92 & 73 & 69 & 62 & 52 & 90 & 78 & 83 \\
\hline Capital cost (\% of total) & 8 & 27 & 31 & 38 & 48 & 10 & 22 & 17 \\
\hline
\end{tabular}

Table 5: Range of loan received by the fishermen on investment and fishing operation in the SME.

\begin{tabular}{|l|l|l|l|l|l|l|l|l|}
\hline Gear & H & B & BJ & C & CJ & G & K & Kp \\
\hline 1. Capital cost & 6484 & 27673 & 24380 & 36568 & 54810 & 9520 & 32730 & 12075 \\
\hline 1.1 Loan for 35\% Coverage & 2269 & 9685 & 8533 & 12799 & 19184 & 3332 & 11456 & 4226 \\
\hline 1.1.1 Interest & 958 & 4089 & 3603 & 5404 & 8099 & 1407 & 4837 & 1784 \\
\hline 1.2 Loan for 45 \% coverage & 2918 & 12453 & 10971 & 16455 & 24665 & 4284 & 14729 & 5434 \\
\hline 1.2.1 Interest & 1232 & 5257 & 4632 & 6948 & 10413 & 1809 & 6218 & 2294 \\
\hline 1.3 Mean interest & 1095 & 4673 & 4117 & 6176 & 9256 & 1608 & 5527 & 2039 \\
\hline 2. Operating cost & 24052 & 54674 & 34713 & 47506 & 49977 & 65768 & 83836 & 45317 \\
\hline 2.1 Loan for 50\% coverage & 12026 & 27337 & 17357 & 23753 & 24988 & 32884 & 41918 & 22659 \\
\hline 2.1.1 Interest & 5077 & 11542 & 7328 & 10029 & 10550 & 13884 & 17698 & 9566 \\
\hline
\end{tabular}




\begin{tabular}{|l|l|l|l|l|l|l|l|l|}
\hline 2.2 Loan for 60 \% coverage & 14431 & 32804 & 20828 & 28504 & 29986 & 39461 & 50301 & 27190 \\
\hline 2.2.1 Interest & 6093 & 13850 & 8794 & 12034 & 12660 & 16660 & 21237 & 11480 \\
\hline 2.3. Mean interest & 5585 & 12696 & 8061 & 11031 & 11605 & 15272 & 19467 & 10523 \\
\hline 3. Mean total interest & 3340 & 8685 & 6089 & 8603 & 10431 & 8440 & 12497 & 6281 \\
\hline
\end{tabular}

Table 6: Estimated daily catch rate $\left(\mathrm{kg} \mathrm{day}^{-1}\right)$ of Giant Freshwater Prawn, by different gears in SME

\begin{tabular}{|c|c|c|c|c|c|c|}
\hline Gear name & $\begin{array}{l}\text { Gear } \\
\text { No. }\end{array}$ & $\begin{array}{c}\text { Peak season } \\
\left(\text { kg day }^{-1} \text { gear }^{-1}\right) \\
\text { Mean } \pm \text { SD } \\
\text { (Min.-Max.) }\end{array}$ & $\begin{array}{c}\text { Lean season } \\
\left(\text { kg day }^{-1} \text { gear }^{-1}\right) \\
\text { Mean } \pm \text { SD } \\
\text { (Min.-Max.) }\end{array}$ & $\begin{array}{c}\text { Medium season } \\
\left(\text { kg day }^{-1} \text { gear }^{-1}\right) \\
\text { Mean } \pm \text { SD } \\
\text { (Min.-Max.) }\end{array}$ & $\begin{array}{c}\text { Annual } \\
\left(\mathrm{kg} \mathrm{boat}^{-1} \mathrm{day}^{-1}\right) \\
\text { Mean } \pm \mathrm{SD} \\
\text { (Min.-Max.) } \\
\end{array}$ & $\begin{array}{c}\text { Total annual } \\
\text { catch } \\
\left(\mathrm{kg} \mathrm{boat}^{-1} \mathrm{yr}^{-1}\right)\end{array}$ \\
\hline Behundijal & 168 & $\begin{array}{l}0.50 \pm 0.15 \\
(0.29-0.91)\end{array}$ & $\begin{array}{l}0.42 \pm 0.18 \\
(0.01-0.47)\end{array}$ & $\begin{array}{c}0.47 \pm 0.77 \\
(0.12-0.52)\end{array}$ & $\begin{array}{c}0.93 \pm 0.91 \\
(0.14-0.63)\end{array}$ & $157.73 \pm 35.22$ \\
\hline Badha jal & 116 & $\begin{array}{c}1.05 \pm 0.81 \\
(0.84-1.46)\end{array}$ & $\begin{array}{c}0.94 \pm 0.13 \\
(0.18-0.99)\end{array}$ & $\begin{array}{l}1.00 \pm 0.67 \\
(0.45-1.05)\end{array}$ & $\begin{array}{l}0.99 \pm 0.27 \\
(0.48-1.16)\end{array}$ & $168.88 \pm 36.99$ \\
\hline Charpata & 162 & $\begin{array}{c}0.51 \pm 0.20 \\
(0.30-0.92)\end{array}$ & $\begin{array}{c}0.21 \pm 0.18 \\
(0.00-0.26)\end{array}$ & $\begin{array}{c}0.41 \pm 0.65 \\
(0.16-0.46)\end{array}$ & $\begin{array}{l}0.91 \pm 0.69 \\
(0.15-0.54)\end{array}$ & $156.89 \pm 51.21$ \\
\hline Chandijal & 301 & $\begin{array}{c}0.13 \pm 0.10 \\
(0.02-0.54)\end{array}$ & $\begin{array}{c}0.07 \pm 0.25 \\
(0.01-0.12)\end{array}$ & $\begin{array}{l}0.09 \pm 0.65 \\
(0.03-0.14)\end{array}$ & $\begin{array}{c}0.96 \pm 0.43 \\
(0.02-0.26)\end{array}$ & $172.24 \pm 22.45$ \\
\hline Gillnet & 169 & $\begin{array}{c}0.24 \pm 0.26 \\
(0.13-0.65)\end{array}$ & $\begin{array}{c}0.15 \pm 0.35 \\
(0.09-0.20)\end{array}$ & $\begin{array}{l}0.18 \pm 0.45 \\
(0.12-0.23)\end{array}$ & $\begin{array}{c}0.94 \pm 0.60 \\
(0.11-0.36)\end{array}$ & $166.89 \pm 64.31$ \\
\hline Hookline & 276 & $\begin{array}{c}0.20 \pm 0.21 \\
(0.09-0.61)\end{array}$ & $\begin{array}{c}0.12 \pm 0.31 \\
(0.00-0.17)\end{array}$ & $\begin{array}{l}0.16 \pm 0.97 \\
(0.10-0.21)\end{array}$ & $\begin{array}{c}0.99 \pm 0.42 \\
(0.06-0.33)\end{array}$ & $172.82 \pm 53.22$ \\
\hline Kathijal & 105 & $\begin{array}{c}1.06 \pm 0.23 \\
(0.35-1.47)\end{array}$ & $\begin{array}{l}0.95 \pm 0.17 \\
(0.13-1.00)\end{array}$ & $\begin{array}{l}0.99 \pm 0.48 \\
(0.23-1.04)\end{array}$ & $\begin{array}{c}1.00 \pm 0.96 \\
(0.24-1.17)\end{array}$ & $171.06 \pm 36.55$ \\
\hline KhalPata & 131 & $\begin{array}{c}0.59 \pm 0.30 \\
(0.21-1.00)\end{array}$ & $\begin{array}{c}0.29 \pm 0.66 \\
(0.07-0.34)\end{array}$ & $\begin{array}{c}0.39 \pm 0.84 \\
(0.13-0.44)\end{array}$ & $\begin{array}{c}0.84 \pm 0.84 \\
(0.13-0.59)\end{array}$ & $152.08 \pm 61.52$ \\
\hline
\end{tabular}

Table 7: Estimated rate of Giant Freshwater Prawn catch per unit effort (CPUE) by using different gears 


\begin{tabular}{|c|c|c|c|c|c|c|c|c|c|}
\hline CPUE & $\begin{array}{l}\text { Fishing } \\
\text { season }\end{array}$ & Behundijal & Badha jal & Charpata & Chandi jal & Gill net & Hookline & Kathijal & Khal Pata \\
\hline \multirow{4}{*}{$\begin{array}{l}\text { Mean } \pm \text { SD of } \\
\text { CPUE } \\
\text { (kg/boat/day) }\end{array}$} & Peak & $1.00 \pm 0.014$ & $1.05 \pm 0.22$ & $1.24 \pm 0.74$ & $1.29 \pm 0.76$ & $1.19 \pm 0.99$ & $1.24 \pm 1.20$ & $1.06 \pm 1.32$ & $1.17 \pm 1.33$ \\
\hline & Lean & $0.84 \pm 0.68$ & $0.94 \pm 0.15$ & $0.50 \pm 0.36$ & $0.69 \pm 0.34$ & $0.74 \pm 0.25$ & $0.75 \pm 0.65$ & $0.95 \pm 1.02$ & $0.57 \pm 0.98$ \\
\hline & Medium & $0.93 \pm 0.63$ & $1.00 \pm 1.25$ & $0.99 \pm 1.36$ & $0.89 \pm 0.58$ & $0.89 \pm 0.75$ & $0.99 \pm 0.98$ & $0.99 \pm 1.12$ & $0.77 \pm 0.65$ \\
\hline & Annual & $0.93 \pm 0.08$ & $0.99 \pm 0.06$ & $0.91 \pm 0.37$ & $0.96 \pm 0.31$ & $0.94 \pm 0.23$ & $0.99 \pm 0.25$ & $1.00 \pm 0.06$ & $0.84 \pm 0.31$ \\
\hline \multirow{4}{*}{$\begin{array}{l}\text { Mean } \pm \text { SD of } \\
\text { CPUE } \\
\text { (kg/boat/trip) }\end{array}$} & Peak & $7.01 \pm 4.25$ & $7.33 \pm 3.17$ & $8.65 \pm 6.25$ & $9.04 \pm 4.12$ & $8.34 \pm 2.63$ & $8.67 \pm 1.65$ & $7.43 \pm 6.35$ & $8.20 \pm 3.52$ \\
\hline & Lean & $5.89 \pm 1.69$ & $6.56 \pm 2.65$ & $3.52 \pm 1.25$ & $4.84 \pm 0.99$ & $5.19 \pm 2.45$ & $5.22 \pm 2.11$ & $6.66 \pm 3.12$ & $4.00 \pm 1.22$ \\
\hline & Medium & $6.52 \pm 3.22$ & $6.98 \pm 2.14$ & $6.94 \pm 3.24$ & $6.24 \pm 1.65$ & $6.24 \pm 1.65$ & $6.94 \pm 1.65$ & $6.94 \pm 1.65$ & $5.40 \pm 2.35$ \\
\hline & Annual & $6.48 \pm 0.56$ & $6.95 \pm 0.39$ & $6.37 \pm 2.61$ & $6.71 \pm 2.14$ & $6.59 \pm 1.60$ & $6.94 \pm 1.73$ & $7.01 \pm 0.39$ & $5.87 \pm 2.14$ \\
\hline \multirow{4}{*}{$\begin{array}{l}\text { Mean } \pm \text { SD of } \\
\text { CPUE } \\
\text { (kg/boat/season) }\end{array}$} & Peak & $86.15 \pm 36.25$ & $90.02 \pm 54.25$ & $106.32 \pm 43.69$ & $111.09 \pm 15.36$ & $102.49 \pm 32.25$ & $106.51 \pm 26.35$ & $91.31 \pm 22.14$ & $100.77 \pm 26.33$ \\
\hline & Lean & $15.84 \pm 11.03$ & $16.95 \pm 8.12$ & $16.86 \pm 9.21$ & $15.16 \pm 10.24$ & $15.16 \pm 11.31$ & $16.86 \pm 4.11$ & $16.86 \pm 7.22$ & $13.12 \pm 6.32$ \\
\hline & Medium & $54.72 \pm 31.22$ & $60.89 \pm 23.41$ & $32.69 \pm 21.21$ & $44.97 \pm 28.25$ & $48.22 \pm 24.66$ & $48.43 \pm 17.21$ & $61.87 \pm 24.22$ & $37.17 \pm 11.14$ \\
\hline & Annual & $52.24 \pm 35.22$ & $55.95 \pm 36.79$ & $51.96 \pm 47.74$ & $57.07 \pm 49.10$ & $55.29 \pm 44.09$ & $57.27 \pm 45.47$ & $56.68 \pm 37.50$ & $50.35 \pm 45.29$ \\
\hline \multirow{4}{*}{$\begin{array}{l}\text { Mean } \pm \text { SD of } \\
\text { CPUE } \\
\text { (kg/day/man) }\end{array}$} & Peak & $0.50 \pm 0.14$ & $0.52 \pm 0.12$ & $0.35 \pm 0.11$ & $0.22 \pm 0.38$ & $0.30 \pm 0.37$ & $0.62 \pm 0.39$ & $0.18 \pm 0.20$ & $0.39 \pm 0.32$ \\
\hline & Lean & $0.42 \pm 0.32$ & $0.47 \pm 0.14$ & $0.14 \pm 0.16$ & $0.12 \pm 0.33$ & $0.19 \pm 0.14$ & $0.37 \pm 0.40$ & $0.16 \pm 0.19$ & $0.19 \pm 0.33$ \\
\hline & Medium & $0.47 \pm 0.52$ & $0.50 \pm 0.36$ & $0.28 \pm 0.19$ & $0.15 \pm 0.21$ & $0.22 \pm 0.53$ & $0.50 \pm 0.25$ & $0.17 \pm 0.14$ & $0.26 \pm 0.37$ \\
\hline & Annual & $0.46 \pm 0.04$ & $0.50 \pm 0.03$ & $0.26 \pm 0.11$ & $0.16 \pm 0.05$ & $0.24 \pm 0.06$ & $0.50 \pm 0.12$ & $0.17 \pm 0.01$ & $0.28 \pm 0.10$ \\
\hline
\end{tabular}

Peak season = December, January and February (full dry winter season); Lean season = May, June, July and August (one third of pre-

monsoon and three fourth of monsoon); Medium season = March, April, September, October and November (two third of the pre-monsoon and full of the post-monsoon)

Table 8: Partial budgeting analysis for different Giant Freshwater Prawn fishing units per trip in the SME, Bangladesh. 


\begin{tabular}{|c|c|c|c|c|c|c|c|c|}
\hline Item & $\mathrm{B}$ & $\mathrm{BJ}$ & $\mathrm{C}$ & CJ & $\mathrm{G}$ & $\mathrm{H}$ & $\mathrm{K}$ & KP \\
\hline A. Total production (Kg/trip) & 6.48 & 6.95 & 6.37 & 6.71 & 6.59 & 6.94 & 7.01 & 5.87 \\
\hline B. Total revenue (Tk/trip) & 1442.90 & 1549.48 & 1419.80 & 1494.89 & 1468.90 & 1546.88 & 1562.48 & 1307.73 \\
\hline C. Working capital (Operating costs) & 2278.07 & 1446.39 & 1979.42 & 2082.36 & 2740.31 & 1002.18 & 3493.15 & 1888.22 \\
\hline D. Net revenue (B-C) & -835.17 & 103.09 & -559.62 & -587.47 & -1271.42 & 544.70 & -1930.67 & -580.49 \\
\hline E. Total investment & 3100.74 & 2087.23 & 3211.49 & 3970.28 & 3047.40 & 1094.38 & 4491.10 & 2278.32 \\
\hline F. ROI (B-C)/E*100, \%) & -26.93 & 4.94 & -17.43 & -14.80 & -41.72 & 49.77 & -42.99 & -25.48 \\
\hline J. Depreciation (DP) & 330.35 & 375.00 & 291.59 & 395.83 & 89.58 & 177.96 & 365.80 & 113.02 \\
\hline K. Capital cost $(\mathrm{CP})$ & 1153.02 & 1015.83 & 1523.65 & 2283.75 & 396.67 & 270.16 & 1363.75 & 503.13 \\
\hline L. PBP (yr) (CP/(NR+DP) & -2.28 & 2.12 & -5.68 & -11.92 & -0.34 & 0.37 & -0.87 & -1.08 \\
\hline M. Production cost $\mathrm{kg}^{-1}(\mathrm{C} / \mathrm{A})$ & 351.77 & 207.99 & 310.63 & 310.37 & 415.66 & 144.35 & 498.12 & 321.71 \\
\hline N. Revenue $\mathrm{kg}^{-1}$ production (B/A) & 222.81 & 222.81 & 222.81 & 222.81 & 222.81 & 222.81 & 222.81 & 222.81 \\
\hline O. BCO (B/E) & 0.47 & 0.74 & 0.44 & 0.38 & 0.48 & 1.41 & 0.35 & 0.57 \\
\hline Break-even price (Tk) & 351.77 & 207.99 & 310.63 & 310.37 & 415.66 & 144.35 & 498.12 & 321.71 \\
\hline Break-even production $(\mathrm{Kg})$ & 10.22 & 6.49 & 8.88 & 9.35 & 12.30 & 4.50 & 15.68 & 8.47 \\
\hline$\%$ of operating cost on total investment & 73.47 & 69.30 & 61.64 & 52.45 & 89.92 & 91.57 & 77.78 & 82.88 \\
\hline
\end{tabular}

Values are in US\$, 1 US\$ = Tk. 65.00 in November 2006

Table 9: Partial budgeting analysis for different Giant Freshwater Prawn fishing units per year in the SME, Bangladesh.

\begin{tabular}{|c|c|c|c|c|c|c|c|c|}
\hline Item & $\mathrm{B}$ & $\mathrm{BJ}$ & $\mathrm{C}$ & $\mathrm{CJ}$ & $\mathrm{G}$ & $\mathrm{H}$ & $\mathrm{K}$ & $\mathrm{KP}$ \\
\hline A. Total production $(\mathrm{kg} / \mathrm{yrs})$ & 157.73 & 168.88 & 156.89 & 172.24 & 166.89 & 172.82 & 171.06 & 152.08 \\
\hline B. Total revenue (Tk/yrs) & 35144.36 & 37628.69 & 34955.96 & 38377.33 & 37185.30 & 38506.56 & 38114.41 & 33885.48 \\
\hline C. Working capital (Operating costs) & 54673.65 & 34713.47 & 47506.07 & 49976.62 & 65767.50 & 24052.27 & 83835.56 & 45317.23 \\
\hline D. Net revenue (B-C) & -19529.30 & 2915.22 & -12550.12 & -11599.30 & -28582.21 & 14454.29 & -45721.14 & -11431.75 \\
\hline E. Total investment & 74417.86 & 50093.47 & 77075.70 & 95286.62 & 73137.50 & 26265.21 & 107786.30 & 54679.73 \\
\hline F. ROI (B-C)/E*100, \%) & -26.24 & 5.82 & -16.28 & -12.17 & -39.08 & 55.03 & -42.42 & -20.91 \\
\hline J. Depreciation (DP) & 7928.29 & 9000.00 & 6998.09 & 9500.00 & 2150.00 & 4270.96 & 8779.26 & 2712.50 \\
\hline K. Capital cost (CP) & 27672.50 & 24380.00 & 36567.72 & 54810.00 & 9520.00 & 6483.90 & 32730.00 & 12075.00 \\
\hline L. PBP (yr) (CP/(NR+DP) & -2.39 & 2.05 & -6.59 & -26.11 & -0.36 & 0.35 & -0.89 & -1.38 \\
\hline
\end{tabular}




\begin{tabular}{|c|c|c|c|c|c|c|c|c|}
\hline M. Production cost $\mathrm{kg}^{-1}(\mathrm{C} / \mathrm{A})$ & 346.62 & 205.55 & 302.80 & 290.15 & 394.07 & 139.17 & 490.09 & 297.98 \\
\hline N. Revenue $\mathrm{kg}^{-1}$ production (B/A) & 222.81 & 222.81 & 222.81 & 222.81 & 222.81 & 222.81 & 222.81 & 222.81 \\
\hline O. $\mathrm{BCO}(\mathrm{B} / \mathrm{E})$ & 0.47 & 0.75 & 0.45 & 0.40 & 0.51 & 1.47 & 0.35 & 0.62 \\
\hline Break-even price & 346.62 & 205.55 & 302.80 & 290.15 & 394.07 & 139.17 & 490.09 & 297.98 \\
\hline Break-even production & 245.38 & 155.80 & 213.21 & 224.30 & 295.17 & 107.95 & 376.26 & 203.39 \\
\hline$\%$ of operating cost on total investment & 73.47 & 69.30 & 61.64 & 52.45 & 89.92 & 91.57 & 77.78 & 82.88 \\
\hline
\end{tabular}

Values are in US\$, 1 US\$ = Tk. 65.00 in November 2006.

Table 10. Sensitivity analysis of Giant Freshwater Prawn fishing with different gears in the SME.

\begin{tabular}{|l|l|l|l|l|l|l|l|l|}
\hline $\begin{array}{l}\text { Sensitivity } \\
\text { scenario }\end{array}$ & B & BJ & C & CJ & G & H & K & KP \\
\hline 20\% reduction in market prices & \\
\hline Net revenue & -26558.2 & -4610.5 & -9541.3 & -19275 & -36019 & 6752.97 & -53344 & -18209 \\
\hline ROI & -35.69 & -9.20 & -25.35 & -20.23 & -49.25 & 25.71 & -49.49 & -33.30 \\
\hline PBP & 7927.25 & 8994.71 & 6996.22 & 9497.16 & 2149.74 & 4271.92 & 8778.64 & 2711.84 \\
\hline BCO & 0.38 & 0.60 & 0.36 & 0.32 & 0.41 & 1.17 & 0.28 & 0.50 \\
\hline 30\% reduction in harvest \\
\hline Net revenue & -30072.6 & -8373.4 & -3036.9 & -23112 & -39738 & 2902.32 & -57155 & -21597 \\
\hline ROI & -40.41 & -16.72 & -29.89 & -24.26 & -54.33 & 11.05 & -53.03 & -39.50 \\
\hline PBP & 7927.37 & 8997.09 & 6996.50 & 9497.63 & 2149.76 & 4273.19 & 8778.68 & 2711.94 \\
\hline BCO & 0.33 & 0.53 & 0.32 & 0.28 & 0.36 & 1.03 & 0.25 & 0.43 \\
\hline
\end{tabular}

